\title{
Geografia historyczna w Polsce - rozwój i perspektywy
}

\section{Bogumił Szady}

$\mathbf{P}$ rezentowany artykuł jest próbą uchwycenia najważniejszych linii rozwojowych na polu badań geograficzno-historycznych w Polsce. Nie ma ambicji wyczerpania zagadnienia, które wymaga odrębnego obszernego studium metodologicznego. Ma stanowić jedynie wstęp oraz dać asumpt do dyskusji nad miejscem oraz zadaniami geografii historycznej. Znaczna liczba oraz stopień zróżnicowania opracowań, które ich autorzy lub czytelnicy zaliczają do kategorii prac z zakresu geografii historycznej, skłania do rozważań o charakterze bardziej ogólnym. Bogactwo tematów, ujęć i metod uświadamiają chociażby - zestawienie bibliograficzne J. Szymańskiego do części poświęconej geografii historycznej w podręczniku nauk pomocniczych historiii ${ }^{1}$ czy też przegląd dorobku "geografii historycznej w Polsce po II wojnie światowej", dokonany ostatnio przez M. Kuleszę $^{2}$. Wszechstronnej, szerokiej i bogatej literaturze dotyczącej „krajobrazu geohistorycznego” (termin J. Szymańskiego) w niewielkim stopniu towarzyszy dyskusja metodologiczna, dotycząca omawianego obszaru wiedzy. Problem ten był dostrzegany i wielokrotnie podkreślany już wcześniej³

Rozwój badań naukowych, nowe problemy i stosowane metody wymuszają systematyczną i regularną refleksję, odnoszącą się do samego rozumienia terminu „geografia historyczna”. Pogłębione analizy tej kwestii przynoszą ważne studia ostatnich lat autorstwa A. Bakera ${ }^{4}$ i W. Schenka ${ }^{5}$. Obie prace skłaniają do rozważenia swoistej reasumpcji twierdzenia i uznania geografii historycznej za odrębną dyscyplinę naukową. Zachęca do tego również wspomniana wyżej rozległość, jednocześnie niedookreśloność, zarówno przedmiotu badań, jak też stosowanych metod i celów wyznaczanych geografii historycznej. Nakładają się na to silne różnice w interpretacji i rozumieniu tego pojęcia między poszczególnymi krajami europejskimi, co wynika z odmiennego usytuowania instytucjonalnego badań o charakterze geograficzno-historycznym. Najważniejsze w tym kontekście jest odniesienie do utrwalonych już dyscyplin naukowych: geografii i historii.

Cytowani wyżej autorzy, uwzględniając bogaty i różnorodny dorobek nauki europejskiej na tym polu, wyraźnie poszukują pewnej tożsamości ontologicznej (właściwości konstytutywnych) pojęcia "geografia historyczna”. A. Baker pisze:

„Far from suggesting that the scope and purpose of historical geography should be narrowed, I argue that it should be enlarged. It is not my intention to refine a purist definition of historical geography as a discipline or sub-discipline. I will instead argue the merits of historical geography as an interdisciplinary project, offering a number of distinctive perspectives upon peoples, places and periods in the past"6.

Inni autorzy używają zbliżonych pojęć:

„En effet, face aux courants qui l'ont fait voir comme une sous-discipline, et à ceux qui l'ont vue comme une science autonome, plus géographique qu'historique, s'impose de plus en plus l'idée aujourd'hui d'une inter-discipline appliquée à l'étude de l'espace historique et nourrie des idées, du langage et des methods des deux disciplines"7.

„Der Gebrauch des Terminus «Historische Geographie» hat damit heute vor allem die

\footnotetext{
${ }^{1}$ J. Szymański, Nauki pomocnicze historii, Warszawa 2006, s. 236-251.

${ }^{2}$ M. Kulesza, Uwagi na temat geografii historycznej w Polsce po II wojnie światowej, w: Geografia historyczna jako determinanta rozwoju nauk humanistycznych, Legnica-Łódź 2009, s. 7-26.

${ }^{3} \mathrm{~J}$. Tyszkiewicz, Człowiek w środowisku geograficznym Polski średniowiecznej, Warszawa 1981, s. 21; J. Janczak, Geografia historyczna - samodzielna dyscyplina czy tylko nauka pomocnicza?, w: Ojczyzna blizsza i dalsza. Studia historyczne ofiarowane Feliksowi Kirykowi w sześćdziesiątą rocznicę urodzin, red. J. Chrobaczyński, A. Jureczko, M. Śliwa, Kraków 1993, s. 83-89.

${ }^{4}$ A.R.H. Baker, Geography and History: Bridging the Divide, Cambridge 2003, s. 14-16.

${ }^{5}$ W. Schenk, Historische Geographie, Darmstadt 2011, s. 7-8.

${ }^{6}$ A.R.H. Baker, Geography and History, s. 16.

${ }^{7}$ S. Courville, Introduction à la géographie historique, wyd. 2, Quebec 2004, s. 7.
} 
Funktion einer Markierung der Relevanz des historisch-geographischen Betrachtungsansatzes innerhalb der Geographie. In diesem Sinne versteht sich der Verfasser dieses Buches als Historischer Geograph".

$\mathrm{W}$ nauce polskiej, podobnie jak w innych krajach europejskich, znaczenie i zakres pojęcia "geografia historyczna" budzity kontrowersje i ulegały zmianom. Ważne głosy teoretyczne $\mathrm{w}$ tej sprawie zabierali m.in. S. Arnold $(1929,1951)^{9}$, G. Labuda i M. Dobrowolska $(1953)^{10}$, H. Rutkowski $(1964)^{11}$, J. Szymański $(1976)^{12}$, J. Janczak $(1993)^{13}$ oraz J. Tyszkiewicz (2003) ${ }^{14}$. Od połowy lat 60. ubiegłego stulecia większość autorów, zarówno historyków jak i geografów, zgodnie traktowało geografię historyczną jako odrębną dyscyplinę lub subdyscyplinę naukową: „badającą środowisko geograficzne w przeszłości, jego przemiany i związki z historią społeczeństw oraz przemiany zjawisk przyrodniczych, jak również przestrzennych form zasiedlenia i zagospodarowania ziemi, składających się na środowisko geograficzne i wyrażających się w krajobrazie naturalnym”.

Przytoczona definicja geografii historycznej, wypracowana przez H. Rutkowskiego w 1964 r., jest dość powszechnie akceptowana, czemu dali wyraz K. Chłapowski i H. Szulc ${ }^{15}$.

\section{Instytucje}

Ocena badań geograficzno-historycznych w Polsce musi brać pod uwagę ich obudowę instytucjonalną. Losy instytutów, katedr czy pracowni świadczą bowiem dobrze o kondycji, jak też przemianach zachodzących w ramach określonych obszarów wiedzy. Mają też bezpośrednie przełożenie na intensywność i rozwój prowadzonych prac. Badania o charakterze geogra-

\footnotetext{
${ }^{8}$ W. Schenk, Historische Geographie, s. 6-7.

9 S. Arnold, Geografia historyczna, jej zadania i metody, „Przegląd Historyczny" 28 (1929), nr 1, s. 91-120; tenże, Geografia historyczna Polski, Warszawa 1951, s. 12-13.

${ }^{10} \mathrm{G}$. Labuda, Uwagi o przedmiocie i metodzie geografii historycznej, „Przegląd Geograficzny”, 25 (1953), z. 1, s. 5-56; M. Dobrowolska, Przedmiot i metoda geografii historycznej. Uwagi o referacie prof. dra G. Labudy, „Przegląd Geograficzny”, 25 (1953), z. 1, s. 57-69.

${ }^{11}$ H. Rutkowski, Geografia historyczna, w: Wielka Encyklopedia Powszechna PWN, t. 4, Warszawa 1964, s. 184-185.

12 J. Szymański, Nauki pomocnicze historii, Warszawa 1976, s. 176178.
}

ficzno-historycznym przebiegały równolegle w środowiskach historycznych i geograficznych. Dość wyraźnie rysują się trzy nurty organizacyjne, które na różnych etapach współpracowały ze sobą oraz często skupiały te same osoby: towarzystwa naukowe, centralne instytucje nauki oraz środowiska akademickie.

W pierwszym okresie najważniejszą rolę $\mathrm{w}$ organizacji prac nad geografią historyczną w Polsce odgrywały towarzystwa naukowe. Przed pierwszą wojną światową środowisko geograficzno-historyczne koncentrowało się wokół Towarzystwa Naukowego w Warszawie (A. Jabłonowski, W. Kamieniecki ${ }^{16}$. Tuż po zakończeniu działań wojennych podjęta została próba koordynacji prac atlasowych przez powołanie w 1918 r., przy Polskim Towarzystwie Geograficznym, Komisji Geografii Historycznej. Niepoślednią rolę odgrywał tutaj W. Kamieniecki, najpierw kierujący Gabinetem Geograficzno-Historycznym Akademii Umiejętności (1909-1910), następnie Komisją Geografii Historycznej Polskiego Towarzystwa Geograficznego (od 1918), organizując jednocześnie prace nad mazowiecką częścią Atlasu historycznego Polski ${ }^{17}$. W składzie Komisji, oprócz W. Kamienieckiego, znalazły się osoby o przygotowaniu zarówno historycznym, jak i geograficznym: M. Handelsman, B. Olszewicz, A. Rybarski, L. Sawicki, W. Semkowicz i K. Tymieniecki ${ }^{18}$.

W 1921 r. koordynacja prac atlasowych, na skutek wycofania się W. Kamienieckiego, została przeniesiona do Polskiej Akademii Umiejętności, przy której od 1922 r. funkcjonowała Komisja dla Atlasu Historycznego Polski. $\mathrm{Na}$ jej czele stanął W. Semkowicz, kierując jednocześnie pracami w Krakowie, zaś komisjami w Warszawie, Lwowie i Poznaniu, związanymi

13 J. Janczak, Geografia historyczna.

J. Tyszkiewicz, Geografia historyczna Polski w średniowieczu, Warszawa 2003.

M. Kulesza, Uwagi na temat geografii historycznej, s. 12; K. Chłapowski, W sprawie pojęcia "geografia historyczna”, "Przegląd Geograficzny”, 68 (1996), z. 3-4, s. 479-483 (oraz odpowiedź H. Szulc).

${ }^{16} \mathrm{H}$. Rutkowski, Atlas historyczny Polski w: Towarzystwo Naukowe Warszawskie. Sto lat działalności, red. E. Wolnicz-Pawłowska, W. Zych, Warszawa 2009, s. 115-116.

${ }^{17}$ W. Tatarkiewicz, Kamieniecki Witold, w: Polski Słownik Biograficzny, t. 11, red. E. Rostworowski, Wrocław 1964-1965, s. 520-521.

8 „Przegląd Geograficzny”, 1 (1918), z. 1-2, s. 154-155. 
z miejscowymi towarzystwami naukowymi, kierowali na początku odpowiednio M. Handelsman, F. Bujak i K. Tymieniecki. W okresie późniejszym powstawały kolejne komisje atlasowe w Toruniu (Instytut Bałtycki), Łodzi, Wilnie ${ }^{19}$.

Udział geografów w początkowej fazie rozwoju geografii historycznej w Polsce od samego początku zmierzał w nieco innym kierunku. Wynikało to z zaangażowania większości z nich w pokrewne, a nawet konkurencyjne, dyscypliny: geografię polityczną oraz antropogeografię (E. Romer, W. Nałkowski, J. Smoleński). Można powiedzieć, że podział między geografią historyczną a antropogeografią jest kluczowy dla losów geografii historycznej w Polsce. Nie oznaczał on oczywiście braku kontaktów naukowych. Czynny udział w pracach komisji atlasowych brali m.in. B. Olszewicz czy M. Dobrowolska, wychowanka J. Smoleńskiego i L. Sawickiego, z kolei historycy: W. Semkowicz, K. Buczek, T. Ładogórski byli czynnymi uczestnikami II Zjazdu Słowiańskich Geografów i Etnografów w 1927 r., organizowanego przez L. Sawickiego (podsekcja geografii historycznej i historii geografii) ${ }^{20}$.

Ramy organizacyjne dla rozwoju badań geograficzno-historycznych, często przy pomocy tych samych osób, stwarzały także uniwersytety i szkoły wyższe. Ze środowiska krakowskiego jako uczeń K. Potkańskiego i S. Smolki - zainteresowania geograficzno-historyczne na lwowskim gruncie szerzył F. Bujak, łącząc geografię historyczną z badaniami społeczno-gospodarczymi (Zakład Historii Społeczno-Gospodarczej Uniwersytetu Lwowskiego). W okresie, kiedy F. Bujak był związany z Uniwersytetem Warszawskim, swój doktorat, pod kierunkiem M. Handelsmana, bronił tam S. Arnold, pierwszy kierownik Seminarium Historii Gospodarczo-Społecznej i Geografii Historycznej w Instytucie Historycznym Uniwersytetu Warszawskiego oraz następca M. Handelsmana w warszawskiej komisji atlasowej.

O bardziej historycznym (humanistycznym) niż geograficznym (przyrodniczym) profilu geografii historycznej w Polsce okresu międzywojennego i tuż po zakończeniu wojny (do lat 50.), może świadczyć fakt, że katedry zarówno antropogeografii jak i geografii historycznej tworzone były w ramach Wydziałów Nauk Humanistycznych. Już w 1938 r. na Wydziale Nauk Humanistycznych Uniwersytetu Warszawskiego został po wołany Zakład Antropogeografii, którego kierownikiem został B. Zaborski. W 1945 r. powstał na Uniwersytecie Wrocławskim międzywydziałowy Instytut Geografii i Rozwoju Regionalnego. W jego skład wchodziły dwie katedry Wydziału Nauk Humanistycznych - Katedra Antropogeografii, kierowana przez lwowskiego ucznia E. Romera, J. Wąsowicza oraz Katedra Geografii Historycznej, której kierownikiem został przybyły z Poznania B. Olszewicz. Katedry antropogeografii funkcjonowaty ponadto przy Wydziałach Humanistycznych Uniwersytetu Jagiellońskiego (S. Leszczycki), Uniwersytetu Łódzkiego (S. Gorzuchowski) oraz Uniwersytetu w Toruniu (M. Kiełczewska-Zaleska).

Zasadnicze zmiany $\mathrm{w}$ położeniu geografii historycznej oraz antropogeografii przyniosły decyzje ideologiczne i polityczne przełomu lat 40. i 50. XX wieku. Szczególny nacisk, jaki położono w badaniach na gospodarcze i ekonomiczne uwarunkowania rozwoju społecznego, przełożył się na przekształcenie większości katedr antropogeograficznych w jednostki zajmujące się geografią ekonomiczną, głównie katedry geografii ekonomicznej na wydziałach nauk ścisłych (nauki przyrodnicze, nauki o ziemi). Jako przykład można podać rozporządzenie Ministra Szkół Wyższych i Nauki z 3 marca $1951 \mathrm{r}$. likwidujące katedry antropogeografii na wydziałach humanistycznych Uniwersytetu Wrocławskiego, Łódzkiego oraz Warszawskiego, przy jednoczesnym utworzeniu katedr geografii ekonomicznej na Wydziale Nauk Przyrodniczych we Wrocławiu oraz na Wydziałach Matematyczno-Przyrodniczych w Łodzi i Warszawie.

\footnotetext{
19 „Prace Komisji Atlasu Historycznego Polski, t. 1-5 (1922-1948); W. Semkowicz, Rozwój nauk pomocniczych historii w Polsce, Kraków 1948, s. 33-39; B. Konopska, Polskie atlasy historyczne - koncepcje i realizacje, Warszawa 1994, s. 69-71.

${ }^{20}$ Pamiętnik II Zjazdu Stowiańskich Geografów i Etnografów odbytego w Polsce w roku 1927, red. L. Sawicki, Kraków 1930, t. 2 (szczególnie s. 244-287).
} 
Wcześniej, bo już w 1950 r., podobna sytuacja miała miejsce w Toruniu ${ }^{21}$.

Opisane zmiany organizacyjne dość dobrze pokazują znaczenie dyskusji, jaka odbyła się na wspólnym posiedzeniu Polskiego Towarzystwa Geograficznego i Kierownictwa Badań nad Początkami Państwa Polskiego w Warszawie 4 października 1952 r. (referaty G. Labudy, M. Dobrowolskiej). Zdaniem J. Janczaka powodem spotkania było wydanie w $1951 \mathrm{r}$. podręcznika Geografia historyczna Polski S. Arnolda. Od strony ściśle naukowej można je także wiązać z faktem objęcia przez Kierownictwo Badań nad Początkami Państwa Polskiego prac nad średniowieczną częścią Atlasu historycznego Polski ${ }^{22}$. Sama debata oraz sposób argumentowania, przedstawiony w czasie dyskusji wskazuje jednak, że miała ona wymiar nie tylko merytoryczny. Należy pamiętać, że spotkanie odbyło się w okresie najbardziej intensywnej dyskusji nad kształtem polskiej nauki historycznej, jaka toczyła się w latach 1951-1952 (m.in. konferencja metodologiczna w Otwocku ${ }^{23}$. W tej atmosferze, oprócz przekształcenia większości katedr antropogeograficznych w katedry geografii ekonomicznej, nastąpiła likwidacja wykładów oraz ćwiczeń z geografii historycznej w programach uniwersyteckich studiów historycznych. Nie do końca też mianem sukcesu - tak jak to ujął J. Janczak - można określać utworzenie Zakładu Atlasu Historycznego w Instytucie Historii PAN, który przejął (od 1 lipca 1952 r.) Pracownię Atlasu Historycznego Towarzystwa Naukowego Warszawskiego, reaktywowaną w $1948 \mathrm{r}^{24}$. W rzeczywistości doprowadziło to do rozbicia badań geograficzno-historycznych na dwa nurty, które jeszcze przed wojną próbowały ze sobą współpracować. Nie można zapomi-

${ }^{21}$ Historia geografii polskiej, red. A. Jackowski, S. Liszewski, A. Richling, Warszawa 2008, s. 312, 402, 419, 430.

${ }^{22}$ B. Konopska, Polskie atlasy historyczne, s. 121; F. Sikora, 0 Karolu Buczku jako twórcy „Stownika historyczno-geograficznego ziem polskich w średniowieczu" z garścią wspomnień o nim, w: Karol Buczek (1902-1983). Człowiek i uczony, red. D. Karczewski, J. Maciejewski, Z. Zyglewski, Kraków-Bydgoszcz 2004, s. 40-41.

${ }^{23}$ T.P. Rutkowski, Nauki historyczne w Polsce 1944-1970. Zagadnienia polityczne i organizacyjne, Warszawa 2007, s. 191-230.

${ }^{24}$ Zakład Atlasu Historycznego kierowany przez S. Herbsta objął także pracownie w Toruniu, Wrocławiu, Krakowie i Poznaniu (dwie ostatnie nać bowiem, że w czasie kiedy historycy mieli prowadzić prace atlasowe, w Instytucie Geografii PAN w 1953 r. powstała Pracownia Historii Geografii (od 1956 r. jako Pracownia Historii Geografii i Kartografii), w ramach której działał w latach 1954-1955 zespół badawczy dla geografii historycznej, prowadzony we Wrocławiu przez B. Olszewicza. Nieco później, także w ramach Instytutu Geografii PAN, została utworzona w Warszawie Pracownia Geografii Historycznej, którą kierowała M. Kiełczewska-Zaleska $(1962-1966)^{25}$. Jedyna Katedra Geografii Historycznej na uczelniach wyższych pozostała na Wydziale Nauk Przyrodniczych we Wrocławiu i funkcjonowała do 1973 r. (B. Olszewicz $)^{26}$. W zupełnej opozycji do zmian na szczeblu centralnym poszło utworzenie w 1957 r., przy Katolickim Uniwersytecie Lubelskim, Instytutu Geografii Historycznej Kościoła w Polsce (obecnie Ośrodek Badań nad Geografią Historyczną Kościoła w Polsce).

Kolejnym reorganizacjom oraz przekształceniom instytucjonalnym $\mathrm{w}$ Instytucie Historii Polskiej Akademii Nauk, dotyczącym Atlasu historycznego Polski i Stownika historyczno-geograficznego ziem polskich $w$ średniowieczu ${ }^{27}$, towarzyszyło w latach 60. i 70. XX wieku spadające zainteresowanie geografią historyczną wśród historyków i geografów. W 1966 r. zostaje rozwiązana Pracownia Geografii Historycznej przy Instytucie Geografii PAN, zaś w 1973 r. Katedra Geografii Historycznej we Wrocławiu. Likwidowane są także Pracownie Atlasu Historycznego Polski we Wrocławiu oraz Toruniu. Próba wzmocnienia badań geograficzno-historycznych, przez powołanie Komisji Geografii Historycznej przy Komitecie Nauk Historycznych PAN w 1972 r., nie przyniosła oczekiwanych

przekształcone później w pracownie słownika), J. Janczak, Geografia historyczna, s. 83-84.

T. Kozłowska-Szczęsna, Instytut Geografii i Przestrzennego Zagospodarowania Polskiej Akademii Nauk. Czterdzieści lat działalności 19531993, Warszawa 1994, s. 20-22.

6 J. Piasecka, Geografia historyczna i historia geografii, w: Główne kierunki badań geograficznych ośrodka wrocławskiego, red. J. Łoboda, P. Migoń, Wrocław 2005, s. 155.

${ }^{27}$ Problemy koncepcyjne oraz organizacyjne Atlasu historycznego Polski posiadają już odrębną literaturę przedmiotu, m.in. J. Janczak, Geografia historyczna, s. 84-89; B. Konopska, Polskie atlasy historyczne, s. 120-132. 
rezultatów ${ }^{28}$. Obecnie ramy instytucjonalne dla prowadzenia studiów o charakterze geograficzno-historycznym w Instytucie Historii Polskiej Akademii Nauk tworzą: Pracownia Atlasu Historycznego (M. Słoń) oraz Zakład Słownika Historyczno-Geograficznego Ziem Polskich w Średniowieczu (T. Jurek), w skład którego wchodzą trzy pracownie: Pracownia Słownika Historyczno-Geograficznego Małopolski (W. Bukowski), Pracownia Słownika Historyczno-Geograficznego Wielkopolski (I. Skierska) oraz Zespół Słownika Historyczno-Geograficznego Mazowsza w Średniowieczu (A. Salina). Wyniki swoich badań prezentują one głównie w postaci opracowań o charakterze słownikowym i atlasowym ${ }^{29}$. Warto odnotować udostępnienie większości haseł opracowanych w ramach Stownika historyczno-geograficznego ziem polskich $w$ średniowieczu $\mathrm{w}$ postaci bazy danych i aplikacji internetowej ${ }^{30}$.

Jeszcze większemu rozproszeniu uległy badania o charakterze geograficzno-historycznym prowadzone $\mathrm{w}$ środowiskach geograficznych. Dostrzegalne są trzy dość wyraźne nurty badawcze związane $\mathrm{z}$ historią osadnictwa, geografią polityczną oraz krajobrazem kulturowym. Pewne próby koncentracji badań nad historią osadnictwa oraz historią polityczną, odwołujących się zresztą także do tradycji atlasowej, przeprowadzał Instytut Geografii, od 1974 r. - Instytut Geografii i Przestrzennego Zagospodarowania, Polskiej Akademii Nauk (H. Szulc, P. Eberhardt). Organizatorami najważniejszej powojennej konferencji, poświęconej geografii historycznej osadnictwa w Polsce byli: Sekcja Geografii Osadnictwa i Ludności Polskiego Towarzystwa Geograficznego, Zakład Geografii Społecznej Uniwersytetu Mikołaja

\footnotetext{
${ }^{28}$ M. Kulesza, Uwagi na temat geografii historycznej, s. 21; J. Janczak, Geografia historyczna, s. 86-87. W chwili oddawania artykułu do druku Komisja Geografii Historycznej, zlikwidowana w ramach reorganizacii Komitetu Nauk Historycznych PAN, została przeniesiona do Polskiego Towarzystwa Historycznego.

${ }^{29}$ Ostatnio ukazały się: Województwo krakowskie $w$ drugiej połowie XVI wieku, red. H. Rutkowski, Warszawa 2008; Stownik historyczno-geograficzny województwa krakowskiego w średniowieczu, cz. IV, z. 3: Mieszczyński Staw-Mogilany, red. W. Bukowski, Kraków 2011; Stownik historyczno-geograficzny województwa poznańskiego w średniowieczu, cz. IV, z. 4: Squartnycze - Szytowyeczsko, red. T. Jurek, Poznań 2008.
}

Kopernika w Toruniu oraz Katedra Geografii Politycznej i Studiów Regionalnych Uniwersytetu Łódzkiego ${ }^{31}$. W ramach tej ostatniej, od lat 80., funkcjonuje Zakład Geografii Historycznej i Dziedzictwa Kulturowego (M. Kulesza), współorganizator konferencji na temat geografii historycznej, jakie odbyły się w 2007 i 2009 r. $^{32}$. Z kolei działalność Polskiego Towarzystwa Geopolitycznego oraz Instytutu Geopolityki, wydawcy „Przeglądu Geopolitycznego” (P. Eberhardt), pokazuje jak blisko siebie sytuują się geografia historyczna, geografia polityczna i geopolityka. Dominację ośrodka warszawskiego (M. Rościszewski) oraz łódzkiego (M. Koter) na polu geografii politycznej, widać zarówno w aktywności badawczej, jak i dydaktycznej ${ }^{33}$. Inicjatywą ostatnich lat, która chociażby poprzez tematykę organizowanych konferencji oraz wydawanych materiałów („Prace Komisji Krajobrazu Kulturowego”) wkracza mocno w tradycje geograficzno-historyczne, jest Komisja Krajobrazu Kulturowego przy Polskim Towarzystwie Geograficznym (U. Myga-Piątek).

Bardzo interdyscyplinarnym środowiskiem, uznawanym tradycyjnie za geograficzno-historyczne, są historycy kartografii. Wynika to głównie z faktu wykorzystywania materiałów kartograficznych przez wszystkie nurty badawcze zajmujące się przestrzenią przeszłości, a przede wszystkim przez geografów historycznych i historyków geografii. Tradycje badań F. Bujaka, K. Buczka i B. Olszewicza z powodzeniem kontynuuje Zespół Historii Kartografii przy Instytucie Historii Nauki PAN, który powstał w $1975 \mathrm{r}$. i może być traktowany jako kontynuacja przeniesionej w 1969 r. z Instytutu Geografii PAN - Pracowni Historii Geogra-

\footnotetext{
Stownik historyczno-geograficzny ziem polskich w średniowieczu, edycja elektroniczna, red. T. Jurek, oprac. informatyczne S. Prinke (dostęp: http://www.slownik.hppan.edu.pl/, 19 maja 2012).

${ }^{1}$ Zagadnienia geografii historycznej osadnictwa w Polsce, red. M. Koter, J. Tkocz, Toruń- Łódź 1994, s. 7.

${ }^{32}$ Czas i przestrzeń w naukach geograficznych. Wybrane problemy geografii historycznej, red. M. Kulesza, Łódź 2008; Geografia historyczna jako determinanta rozwoju nauk humanistycznych, red. M. Kulesza, Legnica-Lódź 2009. ${ }_{3}^{3}$ M. Sobczyński, Historia geografii politycznej, w: Historia geografii polskiej, s. 231.
} 
fii i Kartografii. Na mapie polskich ośrodków badawczych i edytorskich, które zajmują się historią kartografii, istotną rolę odgrywa $\mathrm{Za}-$ kład Zbiorów Kartograficznych Biblioteki Narodowej w Warszawie, wydawca serii „Zabytki Polskiej Kartografii” oraz „Studia i Materiały z Historii Kartografii” ${ }^{4}$.

\section{Badania}

Poważnych trudności nastręcza wyłowienie wśród literatury określanej jako geograficznohistoryczna głównych nurtów badawczych. Wynika to nie tylko ze zróżnicowania przedmiotu i metod, określanych czasem potocznie jako ,geograficzno-historyczne", ale także z rozmaitego rozumienia samego pojęcia "geografia historyczna”. Pola badawcze zbiegają się zazwyczaj w pewnym stopniu ze środowiskową afiliacją badań, jednakże nie jest to regułą. Najbardziej upowszechnily się dwa stanowiska klasyfikujące i systematyzujące geografię historyczną - oba oparte o podział według przedmiotu badań. Pierwsze zostało wprowadzone przez H. Rutkowskiego

Tabela. 1. Typologia krajobrazu geograficzno-historycznego

\begin{tabular}{|l|l|}
\hline $\begin{array}{l}\text { Arnold (1929, 1951); } \\
\text { Szymański (1967-2008) }\end{array}$ & $\begin{array}{l}\text { Labuda (1953); } \\
\text { Bohdanowicz, } \\
\text { Dzięcielski (1994-2003) }\end{array}$ \\
\hline $\begin{array}{l}\text { krajobraz naturalny - zespół } \\
\text { Czynników fizjograficznych, krajo- } \\
\text { braz pierwotny, nieprzekształcony } \\
\text { (ukształtowanie powierzchni, kli- } \\
\text { mat, hydrografia, roślinność) }\end{array}$ & $\begin{array}{l}\text { krajobraz naturalny i kulturalny, } \\
\text { rejestrujący wszystkie zmiany } \\
\text { zachodzące w fizycznym krajo- } \\
\text { brazie ziemi }\end{array}$ \\
\cline { 1 - 2 } $\begin{array}{l}\text { krajobraz kulturalny - zmiany } \\
\text { wprowadzone przez człowieka, } \\
\text { historia osadnictwa }\end{array}$ & krajobraz osadniczy \\
\cline { 2 - 2 } krajobraz historyczno-polityczny & krajobraz społeczno-polityczny \\
\hline
\end{tabular}

niku do geografii historycznej i politycznej, grafii historycznej, także w zależności od typów krajobrazu, dzielą oni na trzy nurty: zajmujące się krajobrazem naturalnym i kulturalnym, krajobrazem osadniczym oraz krajobrazem społeczno-politycznym ${ }^{37}$. Kluczowe jest tutaj wyodrębnienie przez G. Labudę „krajobrazu osadniczego" z „krajobrazu kulturalnego”, przy czym dzisiaj częściej stosuje się sformułowanie „krajobraz kulturowy”.

Większość historyków w Polsce nadal utożsamia geografię historyczną ze studiami o chaJ. Bohdanowicz i M. Dzięcielski. Zadania geo- w haśle "geografia historyczna” opublikowanym w Wielkiej Encyklopedii Powszechnej w 1964 r., gdzie autor wyróżnił „dwa zasadnicze kierunki badań: geograficzno-fizyczny, zainteresowany wpływem społeczeństwa na przyrodę, oraz-bardziej rozwinięty od poprzedniego-geograficzno-ekonomicznyihistoryczny, zwracający większą uwagę na wykorzystanie warunków przyrodniczych przez społeczeństwo" ${ }^{35}$. Bardziej ugruntowany w polskiej nauce podział geografii historycznej oparty na typach krajobrazu geohistorycznego - krajobraz naturalny, krajobraz kulturalny (wł. kulturowy), krajobraz historyczno-polityczny - jest wprost przeniesiony z XIX-wiecznej klasyfikacji J. Wimmera ${ }^{36}$. Nieco odmienną klasyfikację i zadania geografii historycznej, na pozór różne od ustaleń S. Arnolda, jednak po głębszej analizie wykazujące wiele podobieństw, przedstawił G. Labuda. Schemat ten powtórzyli ostatnio, w podręcz-

rakterze słownikowo-atlasowym, dotyczącymi przede wszystkim osadnictwa oraz podziałów administracyjnych świeckich i kościelnych. Jedynie prace o charakterze monograficznym realizują pełniejszy program geograficzno-historyczny, sprecyzowany przez S. Arnolda ${ }^{38}$ i potwierdzony przez J. Szymańskiego ${ }^{39}$ (krajobraz naturalny, krajobraz kulturalny, krajobraz

${ }^{34}$ S. Alexandrowicz, Rozwój badań nad historią staropolskiej kartografii w latach 1918-1984, w: Dorobek polskiej historii kartografii, red. J. Janczak, W. Wernerowa, Warszawa 1993, s. 27-49; B. Olszewicz, Dorobek polskiej historii geografii i kartografii w latach 1945-1969, Warszawa 1971, s. 8-9.

35 T. P. Rutkowski, Geografia historyczna, s. 184-185

36 J. Wimmer, Historische Landschaftskunde, Innsbruck 1885, s. 12.

${ }^{37}$ G. Labuda, Uwagi o przedmiocie imetodzie geografii historycznej, s. 45; J. Bohdanowicz, M. Dzięcielski, Zarys geografii historycznej i politycznej cywilizacji, Gdańsk 1996, s. 13-19.

${ }^{38}$ S. Arnold, Geografia historyczna, jej zadania i metody, s. 95.

39 J. Szymański, Nauki pomocnicze historii, s. 200-201; A. Gieysztor, Zarys nauk pomocniczych historii, Warszawa 1948. 
historyczno-polityczny, horyzont geograficzny, historia kartografii i kartografia historyczna) ${ }^{40}$.

Najstarszy i najdłużej trwający nurt w polskiej geografii historycznej zajmuje się „badaniem krajobrazu historyczno-politycznego", zaś wyniki swoich działań prezentuje głównie w postaci prac atlasowych oraz słownikowych ${ }^{41}$. Program i zadania geografii historycznej w Polsce jako pierwszy w sposób teoretyczny, przedstawił S. Smolka na pierwszym zjeździe historyków w Krakowie w 1880 r. W przedmiocie badań geografia historyczna miała zajmować się: granicami oraz podziałami administracyjnymi (świeckimi oraz kościelnymi), strukturą własnościową oraz kolonizacją ziem ruskich i litewskich. Zarówno tematyka jak też propozycje źródeł, które miały służyć realizacji zaproponowanych tematów, wskazują, że S. Smolka nie brał wcale pod uwagę roli środowiska przyrodniczego jako przedmiotu badań. Nie dostrzegał także mapy jako źródła historycznego, lecz jej rolę widział w przedstawieniu wyników badań geograficzno-historycznych ${ }^{42}$. Zresztą jego postulat, nie wiadomo czy świadomie, czy przypadkiem (opinia F. Bujaka) - wykorzystania mapy Chrzanowskiego jako podkładu dla map historycznych - został zrealizowany przez atlas ziem ruskich A. Jabłonowskiego ${ }^{43}$. W podobnym duchu - jako kartografię historyczną - geografię historyczną ujmowała większość historyków przełomu XIX i XX wieku, wprowadzając ją powoli do kanonu nauk pomocniczych historii. Do tego nurtu jest zaliczana także Geografia historyczna Z. Glogera, choć inspirowana była $\mathrm{z}$ pewnością także doświadczeniem i pasją etnograficzną, bardzo żywą w polskiej historiografii przełomu wieków.

\footnotetext{
${ }^{40}$ Należą do nich np. opracowania związane z Atlasem historycznym Polski, które zawierają zawsze omówienie krajobrazu naturalnego (środowisko geograficzne), historyczno-politycznego (podziały administracyjne) oraz kulturowego (osadnictwo, nazewnictwo, drogi); J. Tyszkiewicz, Geografia historyczna Polski; G. Błaszczyk, Geografia historyczna Wielkiego Księstwa Litewskiego. Stan i perspektywy badań, Poznań 2012.

${ }^{41} \mathrm{~S}$. Arnold, Geografia historyczna, jej zadania i metody, s. 116.

${ }^{42}$ Pamiętnik Pierwszego Zjazdu Historycznego Polskiego imienia Jana Długosza, odbytego w Krakowie w czterechsetną rocznicę jego śmierci, wyd. M. Bobrzyński, M. Sokołowski, Kraków 1881, s. 133-139.

${ }^{43}$ Ziemie Ruskie Rzeczypospolitej: epoka z przełomu wieku XVI-go na XVII-sty, oprac. A. Jabłonowski, Warszawa-Wiedeń 1889-1904 (Atlas
}

Najważniejszą inicjatywą naukową i wydawniczą, mieszczącą się w tym nurcie geografii historycznej, jest Atlas historyczny Polski ${ }^{44}$. Po wielu dyskusjach nad kształtem atlasu, od połowy lat 60. XX wieku utrzymuje się koncepcja „atlasu” i „słownika”, polegająca na systematycznym opracowywaniu haseł $\mathrm{dla}$ wszystkich miejscowości rejestrowanych przez źródła do końca XVI wieku oraz edycji szczegółowych map, zawierających pełną sieć osadniczą z uwzględnieniem charakteru i wielkości osiedli oraz ich przynależności własnościowej wraz z granicami administracyjnymi, siecią komunikacyjną na tle rzeźby i pokrycia terenu. Generalnie zarzucona została koncepcja opracowania map przekrojowych i syntetyzujących. Propozycje S. Herbsta, nawiązujące zresztą w pewien sposób do cytowanej wyżej myśli S. Smolki, sugerujące wykorzystanie najstarszych map triangulacyjnych jako podkładów dla opracowań atlasowych dotyczących przekroju XVIII-wiecznego (zamiast rekonstrukcji kartograficznej), nie zostały podjęte ${ }^{45}$. Za nawiązanie do tych idei można uznać inicjatywę edycji tzw. józefińskiej mapy Galicji podjętą w ostatnim okresie przez Polską Akademię Nauk (Instytut Historii, Instytut Archeologii i Etnologii, Stacja Naukowa w Wiedniu), Instytut Historii Uniwersytetu Pedagogicznego w Krakowie oraz Instytut Historii Uniwersytetu Rzeszowskiego ${ }^{46}$. Jest szansa, że inicjatywa ta połączy badania z zakresu historii kartografii oraz geografii i kartografii historycznej.

Obok prac nad Atlasem historycznym Polski $\mathrm{w}$ tradycji badań atlasowo-słownikowych mieszczą się inicjatywy Instytutu Geografii Historycznej Kościoła w Polsce (obecnie Ośrodka

historyczny Rzeczypospolitej Polskiej. Dział 2); F. Bujak, Studja geograficzno-historyczne, Kraków 1925, s. 245.

",Perspektywy polskiej geografii historycznej obejmują słowniki geograficzno-historyczne, mapy przeglądowe, kartografię analityczno-syntetyczną", S. Herbst, Atlas na rozdrożu, w: tenże, Potrzeba historii czyli o polskim stylu życia, t. 2, Warszawa 1978, s. 466; Rutkowski, Atlas historyczny Polski, s. 115-121.

${ }^{4}$ S. Herbst, Atlas na rozdrożu, s. 464-469.

${ }^{46}$ W. Bukowski i in., Edycja rękopiśmiennej mapy topograficznej Galicji z lat 1775-1783 (tzw. mapy Miega) z Archiwum Wojennego w Wiedniu, „Kwartalnik Historii Kultury Materialnej”, 59 (2011), nr 1, s. 101-105. 
Badań nad Geografią Historyczną Kościoła w Polsce) w Katolickim Uniwersytecie Lubelskim. Zgromadzony materiał źródłowy oraz szereg studiów szczegółowych, publikowanych w kilku seriach wydawniczych, stanowi doskonałą podstawę dla opracowania syntezy chrześcijaństwa w Polsce. Trwałe miejsce w polskiej geografii historycznej zajęły przede wszystkim opracowania dotyczące dziejów struktur administracyjnych Kościoła katolickiego ${ }^{47}$.

Nieco odmiennie krajobraz historyczno-polityczny postrzegali przedstawiciele dyscyplin geograficznych, przede wszystkim geografii administracyjnej i politycznej oraz geopolityki ${ }^{48}$. Dyscypliny te odwołują się często do polskich badań, dotyczących miejsca Polski w strukturze Europy (E. Romer, W. Nałkowski, O. Halecki). Specjaliści zajmujący się tą problematyką patrzą na granice oraz podziały administracyjne głównie w kontekście długofalowych oraz generalnych przemian. Dokonują syntezy badań geograficzno-historycznych $\mathrm{z}$ wiedzą z zakresu geografii fizycznej, historii administracji czy wiedzą o polityce ${ }^{49}$. Wiele uwagi poświęca się problemowi granic i pograniczy, zarówno politycznych jak też kulturowych (językowych, religijnych i etnicznych $)^{50}$. W opracowaniach pojawiają się takie terminy, jak „krajobraz administracyjny" ${ }^{\text {s1 }}$ czy „przestrzeń geopolityczna” ${ }^{2}$. Towarzyszy temu również - jak w przypadku A. Piskozuba bardziej generalna refleksja filozoficzna ${ }^{53}$, która wpisuje się w nurt dzisiejszej dyskusji nad teorią przestrzeni w geografii i historiii ${ }^{54}$.

${ }^{47}$ M. in. Kościół w Polsce, t. 1-2, red. J. Kłoczowski, Kraków 1969 (zawiera mapy); S. Litak, Atlas Kościoła łacińskiego w Rzeczypospolitej Obojga Narodów w XVIII wieku, Lublin 2006. Zob. też R. Kozyrski, Bibliografia map i planów opracowanych w Instytucie Geografii Historycznej Kościoła w Polsce KUL i wydanych w latach 1956-2000, Lublin 2001.

${ }^{48}$ L. Moczulski, Geopolityka. Korzyści i niebezpieczeństwa, „Przegląd Geopolityczny", 1 (2009), s. 9-10.

${ }^{49}$ P. Eberahardt, Polska i jej granice. Z historii polskiej geografii politycznej, Lublin 2004; A. Piskozub, Dziedzictwo polskiej przestrzeni. Geograficzno-historyczne podstawy struktur przestrzennych ziem polskich, Wrocław 1987, s. 12-22.

${ }^{50}$ Czas i przestrzeń w naukach geograficznych, s. 7-78: Przestrzeń, granice, pogranicza; Geografia historyczna jako determinanta, s. 27-117: Geografia historyczna a badania geograficzno-polityczne państw, granic i pograniczy.

${ }^{51}$ M. Sobczyński, Miejsce i rola powiatu w tradycji podziału terytorialnego Polski, Łódź 2006, s. 5.
Inspiracje etnograficzne, ale przede wszystkim społeczno-gospodarcze leżały u podstaw drugiego - biorąc pod uwage czas powstania - nurtu w polskiej geografii historycznej, którego zadaniem była rekonstrukcja krajobrazu kulturalnego. Za twórców tego nurtu dość zgodnie uznaje się K. Potkańskiego ${ }^{55}$, F. Bujaka ${ }^{56}$ oraz M. Dobrowolskąą . Bardzo mocno zaznaczyła się tutaj dyskusja dotycząca związku między środowiskiem naturalnym (fizjograficznym) a rozwojem osadniczym, uznawanym na początku za główny składnik krajobrazu kulturalnego. Elementy sporu między determinizmem antropogeograficznym F. Ratzla i posybilizmem Vidal de la Blache widać w dwóch podstawowych tekstach metodologicznych, dotyczących geografii historycznej w Polsce: S. Arnolda (1929) i G. Labudy $(1953)^{58}$.

Badania nad geografią historyczną osadnictwa oraz ludności, niezależnie od sporu czy traktować je razem czy odrębnie, umieszczało się niegdyś w zakresie antropogeografii, zaś dzisiaj - geografii człowieka. S. Liszewski, omawiając okres przedwojenny, podzielił studia geograficzno-osadnicze na trzy nurty: zajmujące się badaniem wpływu czynników przyrodniczych i historycznych na rozwój osadnictwa (najbliższy historii), studiami nad osadnictwem wiejskim oraz miastami. Po II wojnie światowej w badaniach geograficzno-historycznych osadnictwa dość wyraźnie wyodrębniają się studia o charakterze: mor-

52 D. Jędrzejczyk, U źródet polskiej myśli geopolitycznej, w: Z problematyki geopolitycznej ziem polskich, red. P. Eberhardt, Warszawa 2008, s. 15-28.

${ }^{33}$ A. Piskozub, Między historiozofią a geozofią, Gdańsk 1994.

${ }^{54}$ A.R.H. Baker, Geography and History, s. 23; P. J. Ethington, Placing the Past: "Groundwork” for Spatial Theory of History, ,Rethinking History", 11 (2007), nr 4, s. 465-493; Ch.W.J. Withers, Place and the "Spatial Turn" in Geography and in History, ,Journal of the History of Ideas", 70 (2009), nr 4, 637-658.

55 K. Potkański, Pisma pośmiertne, oprac. F. Bujak, Poznań 2004 (zwłaszcza część zatytułowana Studia osadnicze), s. 78-262.

56 F. Bujak, Studja geograficzno-historyczne.

${ }^{57}$ M. Dobrowolska, Metody kartograficzne w badaniach osadniczych, w: Pamiętnik IV. Powszechnego Zjazdu Historyków Polskich w Poznaniu 6-8 grudnia 1925, Lwów 1925, t. 1: Referaty, Sekcja VI.

${ }^{58}$ S. Arnold, Geografia historyczna, jej zadania i metody; G. Labuda, Uwagi o przedmiocie i metodzie geografii historycznej. 
fogenetycznym, związane $\mathrm{z}$ badaniami nad morfologią osiedli i ich uwarunkowaniami środowiskowymi (bliższe geografii) oraz socjotopograficzne związane bardziej z badaniami funkcjonalnymi (bliższe historii i naukom społecznym $)^{59}$. Odpowiadają one zresztą „dwuskładnikowości” zjawisk osadniczych: składnik społeczny oraz techniczno-materialny (środowiskowy). Dalsza specjalizacja badań powoduje powstawanie kolejnych subdyscyplin (geografia miast, geografia ludności) oraz rozwój dyskusji metodologicznej (spór między „przyrodnikami” i „humanistami”) ${ }^{60}$.

Badania morfogenetyczne wyrosły $\mathrm{z}$ zainteresowania rozwojem sieci osadniczej, które wyraża się także w pracach o charakterze słownikowo-atlasowym. Studia o charakterze morfogenetycznym, w przypadku miast silnie zintegrowane z urbanistyką i planistyką, zapoczątkowała na szerszą skalę w powojennej Polsce praca M. Kiełczewskiej-Zaleskiej z 1956 r., na temat przeobrażeń wsi pomorskich ${ }^{61}$. Wśród autorów, którzy przy studiach nad osadnictwem umiejętnie łączą metody geograficzne i historyczne, warto wymienić H. Szulc, która zajmując się badaniami morfogenetycznymi wykorzystywała dawne plany wsi oraz metody analizy przestrzennej (metoda analizy sąsiedztwa, metoda metrologii historycznej wsi, metoda tzw. zapisu wstecznego $)^{62}$. Teoretyczne i praktyczne rozważania nad morfogenezą osadnictwa w Polsce, przede wszystkim w zakresie miast, są także udziałem łódzkich geografów J. Dylika ${ }^{63}$, M. Kotera ${ }^{64}$ oraz M. Kuleszy ${ }^{65}$. Pełny przegląd XX-wiecznych badań na temat geografii historycznej osadnictwa, zarówno miejskiego jak i wiejskiego, dali w 1994 roku H. Szulc, M. Koter i M. Kulesza ${ }^{66}$.

Socjotopograficzne podejście do krajobrazu kulturowego koncentruje się na wzajemnym oddziaływaniu struktur przestrzennych i społecznych. Można je wiązać z generalną dyskusją na temat relacji między człowiekiem i środowiskiem oraz postrzeganiem przestrzeni (miejsca) jako efektu relacji kulturowych, społecznych, politycznych i ekonomicznych. W polskiej literaturze przedmiotu najlepiej widać to na przykładzie badań nad miastami. Oprócz szeregu monografii szczegółowych, poświęconych topografii pojedynczych ośrodków miejskich ${ }^{67}$, istotny materiał przynoszą także inicjatywy atlasowe. Poza wspomnianymi wyżej pracami Atlasu historycznego Polski, które poruszają kwestie dotyczące np. struktur własnościowych czy też dróg - szczególne znaczenie ma inicjatywa opracowania Atlasu historycznego miast polskich, która powstała w ośrodku toruńskim, a obecnie jest z powodzeniem kontynuowana

\footnotetext{
${ }^{59}$ S. Liszewski, Geografia osadnictwa w XX i na początku XXI wieku, w: Historia geografii polskiej, s. 162-167. H. Szulc (Osadnictwo wiejskie Polski w pracach geograficzno-historycznych w latach 19181993, w: Geografia osadnictwa i ludności w niepodlegtej Polsce. Lata 1918-1993, red. S. Liszewski, t. 2: Kierunki badań naukowych, Łódź 1994, s. 77-92) wyróziniła w badaniach nad geografią historyczną osadnictwa wiejskiego nurty: społeczno-gospodarczy, prawno-ustrojowy oraz krajobrazowo-geograficzny. M. Koter i M. Kulesza (Badania geograficzno-historyczne osadnictwa miejskiego w Polsce w latach 1918-1993, w: Geografia osadnictwa i ludności w niepodlegtej Polsce, s. 131-160) skupili się głównie na badaniach morfogenetycznych, co wynika z faktu, że do „dorobku geografii historycznej miast zaliczono też wyłącznie - 0 tyle, o ile można było tego dociec - prace, które wyszły spod pióra geografów".

${ }^{60}$ W. Maik, Wprowadzenie, w: Rola i miejsce geografii osadnictwa i ludności w systemie nauk geograficznych, red. S. Liszewski, W. Maik, Bydgoszcz 2005, s. 10-15.

${ }^{61}$ M. Kiełczewska-Zaleska, 0 powstaniu i przeobrażaniu ksztattów wsi Pomorza Gdańskiego, Warszawa 1956; zob. także przegląd tejże autorki: Nowe kierunki studiów geograficzno-historycznych nad osadnictwem wiejskim, „Przegląd Geograficzny”, 35 (1963), z. 1, s. 3-19.

H. Szulc, Plan rękopiśmienny wsi z początku XIX w. jako źródło historyczne, w: Z dziejów kartografii, t. XI: Mapa w pracy historyka, Wrocław-Warszawa 1999, s. 40-44; zob. też jej przegląd: 0 nowych drogach badań w geografii historycznej, „,Zasopismo Geograficzne”, 35 (1964), z. 1, s. 21-28.

${ }^{63} \mathrm{~J}$. Dylik, Województwo ze stolicą bez antenatów. Geografia historyczna województwa tódzkiego, Łódź 1971.

${ }^{64} \mathrm{M}$. Koter, Od fizjonomii do morfogenezy i morfologii porównawczej. Podstawowe zagadnienia teoretyczne morfologii miast, w: Zagadnienia geografii historycznej osadnictwa w Polsce, red. M. Koter, J. Tkocz, Toruń-Łódź 1994, s. 23-32.

${ }^{65}$ M. Kulesza, Zagadnienia morfogenezy i rozplanowania miast średniowiecznych w Polsce, tódź 2011.

${ }^{66}$ Zagadnienia geografii historycznej osadnictwa w Polsce.

${ }^{67}$ Miasta doby feudalnej w Europie środkowo-wschodniej: przemiany społeczne a układy przestrzenne, red. A. Gieysztor, T. Rosłanowski, Warszawa 1976; J. Wiesiołowski, Socjotopografia późnośredniowiecznego Poznania, Warszawa-Poznań 1982. Do ostatnich prac o takim charakterze należą: J. Gordziejew, Socjotopografia Grodna w XVIII w., Toruń 2002; M. Goliński, Wokół socjotopografii późnośredniowiecznej Świdnicy, t. 1-2, Wrocław 2000-2003; K. Mikulski, Socjotopografia Torunia i Elblaga w późnym średniowieczu, Toruń 2006; M. Stoń, Miasta podwójne i wielokrotne w średniowiecznej Europie, Warszawa 2011.
} 
w Krakowie i Wrocławiu ${ }^{68}$. Rosnące w ostatnim czasie zainteresowanie miastami przynosi m.in. Historyczno-topograficzny atlas miast ślaskich, realizowany przez Pracownię Atlasu Historycznego Uniwersytetu Wrocławskiego i Instytutu Herdera w Marburgu, w ramach którego ukazały się już dwa zeszyty o Zgorzelcu i Opolu ${ }^{69}$. Publikacje dotyczące przemian przestrzennych miast pokazują także znaczenie badań z pogranicza geografii historycznej oraz historii sztuki czy też historii kultury materialnej.

Oprócz różnych form osadniczych ważnym elementem krajobrazu kulturowego są szlaki komunikacyjne. Generalnie można je podzielić na naturalne (wodne, powietrzne) oraz będące wynikiem działalności człowieka (drogi lądowe, kolej). Systematyczne badania sieci dróg w Polsce zawdzięczamy Pracowni Atlasu Historycznego Polski, a zwłaszcza A. Dunin-Wąsowicz ${ }^{70}$. Badania nad znaczeniem dróg oraz szlaków komunikacyjnych prowadzone były przede wszystkim przez mediewistów, jednak rzadko stanowiły główny przedmiot zainteresowania czy też odrębną specjalizację ${ }^{71}$. O ile historycy dostrzegali nie tylko ekonomiczny wymiar dróg i szlaków komunikacyjnych ${ }^{72}$, o tyle środowiska geograficzne skupiały się głównie na ich funkcji transportowej i gospodarczej. Najważniejsze badania zawdzięczmy tutaj A. Piskozubowi, który pisał obszernie zarówno o historii transportu morskiego, rzecznego jak i lądowego ${ }^{73}$.

${ }^{68}$ Ostatni tom poświęcony Legnicy został opublikowany w $2010 \mathrm{r}$., Atlas historyczny miast polskich, Legnica, t. 4, z. 6, red. R. Eysymontt, M. Goliński, Wrocław 2010.

${ }^{69}$ Historyczno-topograficzny atlas miast śląskich, t. 1-2, red. P. Haslinger i in., Marburg 2010-2011.

70 T. Dunin-Wąsowicz, Drogami średniowiecznej Polski. Studia z dziejów osadnictwa i kultury, Warszawa 2011.

${ }^{71}$ H. Samsonowicz, Przemiany osi drożnych w Polsce późnego średniowiecza, „Przegląd Historyczny” 64 (1973), z. 4, s. 697-716.

${ }^{72}$ H. Manikowska, Jerozolima - Rzym - Compostela. Wielkie pielgrzymowanie u schytku średniowiecza, Wrocław 2008.

${ }^{73}$ A. Piskozub, Rzeki w dziejach cywilizacji, Toruń 2001; tenże, Morze w dziejach cywilizacji, Toruń 1998; tenże, Transport w dziejach cywilizacji, Toruń 1998

${ }^{74}$ W. Semkowicz, 0 potrzebie i metodzie badań nad krajobrazem pierwotnym, w: Pamiętnik IV. Powszechnego Zjazdu Historyków Polskich w Poznaniu 6-8 grudnia 1925, Lwów 1925, t. 1: Referaty, Sekcja VI.
Zakres rzeczowy i metodologiczny geografii historycznej, w jej dzisiejszym kształcie, dopełniło włączenie w jej obszar badań krajobrazu naturalnego (przyrodniczego). Był to wpływ antropogeograficznej szkoły niemieckiej oraz związanych $\mathrm{z}$ tym nurtem badań nad rekonstrukcją środowiska geograficznego (H. Hettner, J. Wimmer). Wagę tego elementu podkreślił W. Semkowicz na IV Zjeździe Historyków Polskich w Poznaniu w 1925 r. ${ }^{74}$, zaś przypomniał M. Rokosz ${ }^{75}$. Na kształt oraz miejsce badań nad krajobrazem naturalnym mocno wpłynął rozwój nowoczesnych metod oraz daleko posunięta specjalizacja, dotycząca poszczególnych elementów krajobrazu naturalnego - np. geomorfologia, klimatologia, hydrologia czy geobotanika. Integracja badań geograficzno-historycznych $\mathrm{z}$ ustaleniami genetycznych studiów klimatologicznych czy hydrologicznych, jest wciąż postulatem spełnionym w bardzo niewielkim stopniu. Obok ogólnych prac dotyczących przemian środowiska geograficznego (M. Dobrowolska ${ }^{76}$, J. Tyszkiewicz ${ }^{77}$ ) brakuje szczegółowych studiów łączących chociażby metody kartograficzne, historyczne i geograficzne w zakresie zmian zalesienia czy zabagnienia terenów ${ }^{78}$. Opracowania na temat przemian klimatycznych, charakterystyki gleb czy sieci rzecznej, skupiają się głównie na oddziaływaniu elementów krajobrazu przyrodniczego na procesy osadnicze i środowisko człowieka ${ }^{79}$.

${ }^{5}$ M. Rokosz, 0 dalszej potrzebie i aktualnych metodach badań nad krajobrazem pierwotnym, w: Tradycje i perspektywy nauk pomocniczych historii w Polsce, Kraków 1995, s. 229-238.

${ }^{6}$ M. Dobrowolska, Przemiany środowiska geograficznego Polski do XV wieku, Warszawa 1961.

$77 \mathrm{~J}$. Tyszkiewicz, Uwagi nad krajobrazem środkowego Mazowsza i Warszawy w wiekach średnich, „Rocznik Warszawski”, 14 (1976), s. 49-82; tenże, Środowisko naturalne i antroporegiony dorzecza Narwi przed 1000 lat, Wrocław 1975.

${ }^{78} \mathrm{~J}$. Tyszkiewicz, Nauki historyczne i przyrodnicze w badaniach lasów na ziemiach polskich, w: Ziemia i ludzie dawnej Polski: studia z geografii historycznej, red. A. Galos, J. Janczak, Wrocław 1976, s. 7-36. Próbę wykorzystania metod botanicznych do badań historycznych dał W. Szafer, Analiza pytkowa w zastosowaniu do badań historii kultury materialnej człowieka, „Kultura i Społeczeństwo”, 2 (1958), z. 1, s. 50-64.

${ }^{9}$ T. Dunin-Wąsowicz, Klimat jako czynnik ksztaftujący środowisko człowieka w średniowieczu, w: Problemy nauk pomocniczych historii, t. 3 Katowice 1974, s. 17-35. 


\section{Mapy}

Szczególną rolę w badaniach geograficzno-historycznych odgrywają mapy. Można oczywiście zajmować się geografią historyczną bez prezentacji kartograficznej, jednakże pełna analiza zjawisk przestrzennych bez wykorzystania map wydaje się niemożliwa. Sama kartografia, jako odrębna dyscyplina naukowa, powstała kilkadziesiąt lat temu. Wcześniej pojęcia „mapografia” i "kartografia” oznaczały jedynie badanie dawnych map, czyli w zasadzie to samo, co dzisiaj wyraża „historia kartografii” ${ }^{\circ 0}$. Kształt relacji między mapami oraz geografią historyczną zależy od rodzaju map oraz sposobu ich wykorzystania.

Mapa dawna - niezależnie od historycznego czy tradycyjnego rozumienia tego pojęcia - występuje w roli przedmiotu badań historii kartografii. Rozważania koncentrują się tutaj wokół kwestii związanych z autorstwem map, metodami wytwarzania, dokładnością, treściami przez nie przedstawianymi etc. Jako źródło historyczne mapy stanowią cenne, czasami niezbędne, uzupełnienie kwerend i poszukiwań związanych z podziałami administracyjnymi, osadnictwem czy też krajobrazem przyrodniczym. Są podstawowym źródłem informacji dla historyków architektury, urbanistów, planistów czy specjalistów w zakresie morfogenezy jednostek osadniczych. Ich przydatność była doceniana przez historyków i geografów zajmujących się historią horyzontu geograficznego człowieka, czyli historią wiedzy geograficznej. Są także podstawowym budulcem dla kartografii historycznej ${ }^{81}$.

\footnotetext{
${ }^{80}$ Wprowadzenie do kartografii i topografii, red. J. Pasławski, Wrocław 2006, s. 12; A. Ciołkosz, J. Ostrowski, Historia kartografii, w: Historia geografii polskiej, s. 261.

${ }^{81}$ Mapa w pracy historyka, red. T. Bogacz, B. Konopska, Wrocław-Warszawa 1999.

${ }^{82}$ B. Olszewicz, Dorobek polskiej historii geografii i kartografii.

${ }^{83}$ K. Buczek, Stan i potrzeby badań nad dziejami kartografii polskiej, w: Problemy nauk pomocniczych historii. Materiaty na III Konferencje poświęconą naukom pomocniczym historii, red. J. Szymański, Katowice 1974, s. 143-157.

${ }^{84}$ S. Alexandrowicz, Rozwój badań nad historią staropolskiej kartografii.

${ }^{85}$ R. Skrycki, Dzieje kartografii Nowej Marchii do końca XVIII wieku, Warszawa 2008; D. Borowicz, Mapy narodowościowe Górnego Śląska od połowy XIX wieku do II wojny światowej, Wrocław 2004; A. Konias, Kartografia topograficzna Śląska Cieszyńskiego i zaboru
}

Dorobek polskiej historii kartografii, której początki sięgają połowy XIX wieku, był przedmiotem trzech istotnych podsumowań o charakterze historiograficznym i metodologicznym - B. Olszewicza (1971), który ujmował historię kartografii jako część historii geografii ${ }^{82}$, K. Buczka $(1974)^{83}$ oraz S. Alexandrowicza $(1993)^{84}$. Ważnym rysem charakterystycznym $\mathrm{w}$ rozwoju tej dziedziny jest związek większości wybitnych specjalistów z zakresu historii kartografii z pracami atlasowymi oraz kartografią historyczną (F. Bujak. B. Olszewicz, K. Buczek, S. Herbst, J. Janczak). Jedynie S. Alexandrowicz uczynił dawną kartografię, przede wszystkim Wielkiego Księstwa Litewskiego, głównym przedmiotem swoich badań, nie angażując się jednocześnie w prace o charakterze atlasowym. W ostatnich latach następuje dość wyraźna specjalizacja regionalna zainteresowań historyczno-kartograficznych ${ }^{85}$. Dotyczy to zwłaszcza kartografii państw zaborczych. Dzieje polskiej kartografii nie doczekały się jak dotąd pełnego i odrębnego opracowania syntetycznego ${ }^{86}$. Olbrzymie znaczenie dla rozwoju historii kartografii w Polsce oraz prowadzonych na tym polu badań, mają cykliczne konferencje oraz wydawane regularnie tomy „Z Dziejów Kartografii”"

Ważną próbę klasyfikacji oraz określenia zadań historii kartografii przedstawił w $1974 \mathrm{r}$. K. Buczek. Badania tej problematyki, obok prac kartobibliograficznych, powinny uwzględniać „1) stronę czysto historyczną (wiadomości o autorze mapy oraz okolicznościach jej opracowania i publikacji); 2) techniczne

austriackiego od połowy XVIII wieku do początku XX wieku, Katowice 2000; tenże, Kartografia topograficzna państwa i zaboru pruskiego od II połowy XVIII wieku do połowy XX wieku, Słupsk 2010; D. Przybytek, Kartografia historyczna Śląska XVII-XX wieku, Wrocław 2002; B. Czechowicz, Historia kartografii Śląska XII-XIX wieku, Wrocław 2004

${ }^{86}$ Podstawowe ujęcia syntetyczne: K. Buczek, Dzieje kartografii polskiej od XV do XVIII wieku. Zarys analityczno-syntetyczny, Wrocław-WarszawaKraków 1963; M. Sirko, Zarys historii kartografii, Lublin 1999; A. Jackowski, Dzieje geografii polskiej do 1918 roku, w: Historia geografii polskiej, s. 11-73. Obszerną bibliografię podał J. Szymański, Nauki pomocnicze historii, s. 236-251.

7 W. Wernerowa, Dorobek ogólnopolskich konferencji historyków kartografii 1975-1995, w: Dwudziestolecie Zespołu Historii Kartografii, red. J. Ostrowski, W. Wernerowa, Warszawa 1995, s. 29-30. 
wykonanie mapy (tu także legendę, system znaków, podziałkę, ewentualnie podział na arkusze); 3) podstawy matematyczne mapy i analizę ich dokładności; 4) analizę topografii oraz elementów fizjograficznych i osadniczych; 5) stosunek do dawniejszych map danego regionu oraz ocenę mapy na tle wspólnej kartografii polskiej i europejskiej”"88. Podkreślił przy tym, że niewiele monografii realizuje pełny kwestionariusz historyczno-kartograficzny. Dwa z wyżej wymienionych aspektów wyodrębniły się jako osobne nurty badawcze: prace o charakterze kartobibliograficznym (B. Olszewicz ${ }^{89}$, M. Łodyński ${ }^{90}$, F. Uhorczak ${ }^{91}$ ), do których też w pewnym sensie można zaliczyć wydawnictwa źródłowe, oraz analizy dokładności i oceny kartometryczności map dawnych.

Stałym elementem towarzyszącym rozwojowi badań historyczno-kartograficznych są edycje źródłowe map dawnych. Mimo że przedwojenny projekt K. Buczka Monumenta Poloniae Cartographica (1939) nie znalazt jak dotąd kontynuacji, pojawiło się $\mathrm{w}$ okresie powojennym wiele cennych wydawnictw przedstawiających dorobek polskiej kartografii ${ }^{92}$. Szczególną rolę odegrała tutaj seria „Zabytki Polskiej Kartografii" ${ }^{3}$ oraz działalność T. Niewodniczańskiego $^{94}$. Ostatnie inicjatywy wydawnicze, np. Historyczno-topograficzny atlas miast ślaskich czy edycja map Rzeczypospolitej znajdujących się w Sztokholmie pokazują, że dokonuje się w tym obszarze stały postęp zarówno metodyczny, np. łączenie kartografii historycznej z historią kartografii, jak też jakościowy ${ }^{95}$.

\footnotetext{
${ }^{88}$ K. Buczek, Stan i potrzeby badań nad dziejami kartografii polskiej, S. 149.

${ }^{89}$ B. Olszewicz, Kartografia polska XIX wieku. Przegląd chronologicznobibliograficzny, t 1-2, oprac. W. Wernerowa, Warszawa 1998; tenże, Kartografia polska XIX wieku. Przegląd chronologiczno-bibliograficzny, t. 3, oprac. W. Wernerowa, J. Ostrowski, Warszawa 1999; tenże, Kartografia polska XVIII wieku. Przegląd chronologiczno-bibliograficzny, oprac. W. Wernerowa, J. Ostrowski, Warszawa 2003; tenże, Kartografia polska XV-XVII wieku. Przegląd chronologiczno-bibliograficzny, oprac. W. Wernerowa, J. Ostrowski, Warszawa 2004.

${ }^{90}$ Katalog atlasów i dziet geograficznych 1482-1800, red. M. Łodyński, Warszawa 1961; Katalog atlasówi dziet geograficznych 1482-1800 (uzupetnienie), red. M. Łodyński, Warszawa 1963, s. 113; Katalog atlasów 1801-1919, red. M. Łodyński, Warszawa 1965; Katalog atlasów i dzieł geograficznych 1528-1945, red. M. Łodyński, T. Paćko, Warszawa 1968, s. 161.
}

Mapa historyczna w pracach geograficzno-historycznych służy najczęściej do prezentacji wyników badań, rzadziej jako jedna z metod badawczych. Kartografia historyczna, jako istotna gałąź naukowej kartografii tematycznej (podkategoria map społeczno-gospodarczych), narodziła się w XIX wieku. Znaczną część dorobku polskiej kartografii historycznej omówiła B. Konopska w pracy poświęconej polskim atlasom historycznym $^{96}$. J. Szymański wprowadził wewnętrzny podział map historycznych na: mapy inwentaryzacyjne, mapy badawcze oraz mapy wyjaśniające. Kryterium tego podziału jest zarówno treść mapy, jak też cel jej przygotowania związany z konkretnym zadaniem lub etapem pracy historyka ${ }^{97}$. Przedstawiony wyżej podział $\mathrm{z}$ trudem da się zastosować do konkretnych opracowań, np. mapy wykonywane w ramach Atlasu historycznego Polski noszą znamiona zarówno opracowań o charakterze inwentaryzacyjnym jak też badawczym, gdyż zawierają także elementy rekonstrukcji środowiska naturalnego (zalesienie, sieć rzeczna, ukształtowanie powierzchni). Dyskusja wokół kształtu Atlasu historycznego Polski wskazała na inny istotny podział, częściowo zbieżny z przytoczonym powyżej, na mapy szczegółowe i mapy przeglądowe.

Polska kartografia historyczna obejmuje dzisiaj bardzo szeroką i różnorodną problematykę badawczą oraz wyznaczane jej są bardzo różne cele. Obok naukowych atlasów historycznych o charakterze ogólnym (np. Atlas historyczny Polski) szczególne znaczenie dla ukazania krajobrazu kulturowego mają mapy tematyczne związane z sytuacją wyznaniową oraz etnicz-

Wieloarkuszowe mapy topograficzne ziem polskich, 1576-1870, cz. 1, red. T. Paćko, W. Trzebiński, Wrocław 1983, cz. 2, oprac. F. Uhorczak i in., Wrocław 1982.

M.in. Polonia: Atlas map z XVI-XVIII wieku, oprac., wstęp S. Alexandrowicz, L. Szaniawska, Warszawa 2005.

3 Ostatni tom: A. Jodłowski, Obraz Żupy Wielickiej i miasta Wieliczki na mapach Wilhelma Hondiusa z 1645 roku, Warszawa 2005.

Imago Poloniae. Dawna Rzeczpospolita na mapach, dokumentach i starodrukach w zbiorach Tomasza Niewodniczańskiego, red. T. Niewodniczański, t. 1-2, Warszawa 2002

${ }^{95}$ Historyczno-topograficzny atlas miast śląskich; K. Łopatecki, W. Walczak, Mapy i plany Rzeczypospolitej XVII w. znajdujące się w archiwach w Sztokholmie, t. 1-2, Warszawa 2011.

${ }^{96}$ B. Konopska, Polskie atlasy historyczne.

${ }^{97}$ J. Szymański, Nauki pomocnicze historii, s. 228-229. 
no-językową (S. Litak, Z. Budzyński) ${ }^{98}$. Nieco innych charakter - głównie ze względu na większą skalę - mają atlasy miast oraz wsi, związane ze studiami o charakterze morfologicznym czy morfogenetycznym ${ }^{99}$. W ostatnim czasie w kartografii historycznej wykorzystywane są coraz częściej systemy informacji geograficznej (ang. GIS). Wzbogacają one klasyczną kartografię historyczną o bogatą warstwę informacyjną (atrybuty opisowe) i pozwalają użytkownikowi czerpać informacje o każdym obiekcie z interaktywnej aplikacji ${ }^{100}$. Systemy informacji geograficznej zaczynają odgrywać także coraz większą rolę w badaniach oraz analizach o charakterze geograficzno-historycznym ${ }^{101}$.

\section{Zakończenie: Perspektywy}

Przyszłość geografii historycznej w Polsce, ale również $\mathrm{w}$ innych krajach, w zdecydowanie większym stopniu zależy od zmian zachodzących w ramach nauk geograficznych niż historycznych. Usunięcie wykładów oraz ćwiczeń z geografii historycznej z akademickiego kursu historycznego (lata 50. XX wieku) spowodowało, w dłuższym okresie, kryzys badań $\mathrm{w}$ tym zakresie $^{102}$. Zmiany zachodzące $\mathrm{w}$ ramach nauk geograficznych, po okresie silnego rozwoju geografii fizycznej, coraz częściej idą w kierunku intensyfikacji badań z zakresu tzw. "geografii kultury" (cultural geography) oraz "geografii człowieka" (human geography), które to obszary w oczywisty sposób stykają się, lub wręcz zachodzą, na geografię historyczną w jej

${ }_{98}$ S. Litak, Atlas Kościoła łacińskiego; Z. Budzyński, Kresy południowowschodnie w drugiej pofowie XVIII wieku, t. 2, Atlas geograficznohistoryczny, Przemyśl-Rzeszów 2006.

${ }^{99}$ H. Szulc, Atlas historyczny wsi w Polsce, Warszawa 2002; Atlas historyczny miast polskich.

${ }^{100}$ Topodemograficzny atlas gmin i obszarów dworskich Pomorza Zachodniego w 1871 roku, red. D. Chojecki, Szczecin 2012.

${ }^{101}$ B. Szady, Geografia struktur religijnych $i$ wyznaniowych w Koronie w II połowie XVIII wieku, Lublin 2010; K. Wnęk, Własność nieruchomości w Krakowie w połowie XIX w., Kraków 2011.

102 J. Janczak, Geografia historyczna, s. 84.

${ }^{103}$ M. Williams, Epilogue: critique and evaluation, w: H.C. Darby, The Relations of History and Geography: Studies in England, France and the United States, Exeter 2002, s. 206.

${ }^{104}$ W swoim zbiorze esejów na temat geografii historycznej w średniowieczu wielokrotnie wskazuje potrzebę włączenia do badań geograficzno-historycznych wiedzy z innych dyscyplin i subdyscyplin, np. gleboznawstwo, klimatologia, ekologia, botanika, leśnictwo, geopo- klasycznym ujęciu. Niektóre głosy dopuszczają nawet możliwość wchłonięcia geografii historycznej przez geografię kultury czy też badania nad historią środowiska naturalnego ${ }^{103}$.

Geografia historyczna w Polsce, mimo rozwoju badań szczegółowych, nie odpowiedziała na zmiany dokonujące się w zakresie metodologii badań geograficznych oraz historycznych po II wojnie światowej. Do nielicznych głosów apelujących o poszerzenie zakresu geografii historycznej, uwzględniając zmiany spowodowane przede wszystkim przez inter- $\mathrm{i}$ wielodyscyplinarność badań, należą opinie J. Tyszkiewicza ${ }^{104}$. Niezmiernie ciekawe uwagi na temat relacji geografii historycznej w stosunku do geografii politycznej i geopolityki, zgłosił ostatnio $\mathrm{A}$. Piskozub w recenzji książki L. Moczulskiego ${ }^{105}$.

Obok głównych nurtów, które można określić jako „tradycyjne”, wyrosły silne i bardzo aktywne gałęzie, nawiązujące w swoim przedmiocie i metodach do geografii historycznej. W moim odczuciu nie oznacza to - jak interpretuje to M. Kulesza - „renesansu i powtórnego zainteresowania geografią historyczną"106. Jest to rezultat pojawienia się nowych dyscyplin, tematów oraz zagadnień badawczych, które zarówno pod względem przedmiotu, jak też częściowo metod badawczych, pokrywają się z tradycyjnie rozumianą geografią historyczną. Do najważniejszych tematów, obecnych głównie w zakresie nauk geograficznych, które rozwijają geografię historyczną „na swój sposób”, należą badania krajobrazu kulturowego ${ }^{107}$ oraz krajobrazu natu-

lityka, etnologia, antropologia kulturowa etc., J. Tyszkiewicz, Geografia historyczna Polski, s. 10, 11, 17, 18

${ }^{105}$ A. Piskozub, Geografia historyczna międzymorza battycko-czarnomorskiego, rec. Leszek Moczulski: Narodziny Międzymorza. Uksztattowanie ojczyzn, powstanie państw oraz uktady geopolityczne wschodniej części Europy w późnej starożytności i we wczesnym średniowieczu, Wydawnictwo Bellona, Warszawa 2007, ss. 827, „Przegląd Geopolityczny” 3 (2011), s. 221-240.

${ }^{106}$ M. Kulesza, Uwagi na temat geografii historycznej, s. 22.

${ }^{107}$ U. Myga-Piątek, Krajobraz kulturowy w badaniach geograficznych, w: Krajobraz kulturowy. Aspekty teoretyczne i metodologiczne, red. U. Myga-Piątek, Sosnowiec 2005, s. 40-53; taż, Historia, metody i źródła badań krajobrazu kulturowego, „Problemy Ekologii Krajobrazu”, 17 (2005) s. 71-77 (wymienia w nurcie badawczym krajobrazu kulturowego W. Semkowicza, F. Bujaka i M. Dobrowolską); D. Jędrzejczyk, Humanistyczna interpretacja krajobrazu kulturowego, w: Kulturowy aspekt badań geograficznych, red. E. Orłowska, J. Klementowski, Wrocław 2003, s. 68-73. 
ralnego (m.in. ekologia krajobrazu) ${ }^{108}$. Specjaliści zajmujący się tą problematyką, mimo że nawiązują do dawnych działów geografii historycznej, nie wykorzystują, poza dawnymi mapami czy planami, źródeł historycznych i posługują się głównie metodami geograficznymi. Nie uważają się już za geografów historycznych, mimo że odwołują się często do tych samych tradycji naukowych co „ojcowie założyciele” geografii historycznej w Polsce: S. Smolka, K. Potkański, F. Bujak, W. Semkowicz czy S. Arnold.

Polskie życie konferencyjne oraz publikacje naukowe ostatnich dziesięcioleci świadczą, że nastąpiło dość wyraźne zamknięcie środowisk naukowych zajmujących się geografią historyczną lub włączających przedmiot badań i metody klasycznie rozumianej geografii historycznej do nowych dyscyplin i tematów (geografia humanistyczna, geografia kultury, geografia człowieka, geopolityka, historia krajobrazu kulturowego itp.). Dochodzi do tego, że w wydawanych materiałach - nie wiadomo czy jako usprawiedliwienie czy wyrzut - zaznacza się proweniencję dyscyplinarną badacza (historyk, geograf). Brak dyskusji metodologicznej nie pozwala na przygotowanie nowej syntezy i podręcznika akademickiego. Podział na dwie kultury naukowe (C.P. Snow) - humanistyczną oraz przyrodniczą, jaki wystąpił w okresie powojennym, widać przede wszystkim w trudnościach w integrowaniu źródeł, warsztatów badawczych oraz metod - geograficznych i historycznych. Trudno wyobrazić sobie dzisiaj odważne narracje w stylu K. Potkańskiego, który łączył stosowanie metody retrogresywnej oraz wiedzy geograficznej, etnograficznej i onomastycznej z głęboką znajomością krytycznego warsztatu historycznego oraz źródeł historycznych, archeologicznych i kartograficznych ${ }^{109}$. Mimo 130 lat tradycji (licząc od referatu Smolki w 1880 r.) polskiej geografii historycznej nie udało się powołać także naukowego periodyku poświęconego tej problematyce.

W świetle powyższych uwag konieczne staje się ponowne rozważenie miejsca oraz charakteru geografii historycznej na zmienionej, i wciąż zmieniającej się, polskiej mapie naukowej. Wiele prac określanych dzisiaj mianem geo- graficzno-historycznych nie odpowiada w pełni definicji tej dyscypliny naukowej przyjętej w latach 60. ubiegłego wieku i cytowanej wyżej. Czym więc jest geografia historyczna w Polsce na początku XXI wieku i jak należy ją odnosić do „przewrotu przestrzennego" (spatial turn) w naukach humanistycznych ${ }^{110}$. Czy takie pojęcia jak „geohistoria” (F. Braudel) i „geografia historyczna” mogą być używane zamiennie. W jaki sposób na kształt geografii historycznej wpływają nowe technologie w dziedzinie analizy kartograficznej oraz systemy informacji geograficznej (ang. GIS).

Odpowiedź na postawione wyżej pytania nie jest prosta. Błędem będzie najpewniej próba narzucenia nowych ram czy to organizacyjnych, czy to metodologicznych lub pojęciowych, wobec tak zróżnicowanych jak przedstawione wyżej, nurtów badań o charakterze geograficzno-historycznym. Jedne środowiska przyjmą bowiem zaproponowaną klasyfikację jako właściwą, inne natomiast odrzucą jako niedoceniającą wkładu i znaczenia ich nurtu badawczego. Dokonująca się w ostatnich dziesięcioleciach przemiana technologiczna i pojawienie się nowych narzędzi informatycznych, zwalniają w znacznym stopniu z konieczności tworzenia definicji, ram czy zasad dotyczących badań geograficzno-historycznych, poza jakże ogólnym, a jednocześnie ważnym wymogiem rzetelności naukowej i badawczej.

Kluczowe dla dalszego rozwoju geografii historycznej w Polsce jest wznowienie dyskusji metodologicznej nad jej kształtem oraz wymiana danych i informacji, będących wynikiem badań naukowych. Dotyczy to zarówno środowisk historycznych jak i geograficznych, uznawanych lub uznających się za geograficzno-historyczne. Systematyczne spotkania Komisji Geografii Historycznej przy Polskim Towarzystwie Historycznym (od 2011 r.) powinny być wzbogacone ogólnopolską cykliczną konferencją geograficzno-historyczną, na wzór spotkań

\footnotetext{
${ }^{108}$ A. Richling, Perspektywy rozwoju ekologii krajobrazu, „Problemy Ekologii Krajobrazu", 23 (2009), s. 1-10.

${ }^{109}$ K. Potkański, Pisma pośmiertne, s. 78-262.

110 K. Schlögel, W przestrzeni czas czytamy. 0 historii cywilizacji i geopolityce, Poznań 2009 (s. 56-68: Spatial turn, nareszcie).
} 
organizowanych przez historyków kartografii oraz powołaniem czasopisma, którego profil odpowiadałby czeskiemu „Historická geografie” czy angielskiemu "Journal of Historical Geography”.

Jednolitą platformą wymiany oraz współpracy naukowej, naturalną ze względu na przedmiot i metody badawcze (analityczne) geografii historycznej, jest w tym przypadku oczywiście przestrzeń geograficzna. Historia była bowiem zawsze "geohistorią" ${ }^{111}$. Możliwości stworzone przez systemy informacji przestrzennej oraz formaty wymiany danych, pozwalają na wykorzystanie do indywidualnych potrzeb i celów badawczych danych geograficznych, wraz z dołączonymi do nich atrybutami opisowymi, pochodzących z wielu źródeł. Filozofia "chmury informatycznej" (tzw. cloud computing) może być $\mathrm{z}$ powodzeniem przeniesiona na grunt informacji geograficzno-historycznej. Warstwowa architektura stosowana w kartografii historycznej oraz systemach informacji przestrzennej doskonale odpowiada metodologii, zarówno badań geograficznych jak historycznych.

Wymiana danych oraz informacji czasowoprzestrzennych umożliwi szersze zastosowanie badań krzyżowych i to w dwóch wymiarach: metodologicznym (metody badań - geograficzne, historyczne, kartograficzne, onomastyczne, retrogresywne, progresywne itd.) oraz rzeczowym (połączenie tematów - model rodziny, ukształtowanie powierzchni, struktura wyznaniowa, typy osadnicze itd.). Wszystkie dotychczasowe i kolejne badania o charakterze szczegółowym winny być możliwie szybko uzupełniane o kolejne warstwy, w celu pełnego wykorzystania metody geohistorycznej. Za przykład takiej analizy krzyżowej może posłużyć zestawienie wyników badań dotyczących stosunków wyznaniowych (B. Szady) z modelami gospodarstw domowych (M. Szołtysek) w Rzeczypospolitej w II połowie XVIII w. Badania prowadzone $\mathrm{w}$ dwóch różnych ośrodkach (w Polsce i w Niemczech) przy pomocy różnych źródeł oraz metod, zostały połączone dzięki geolokalizacji danych, co pozwoliło określić stopień współzależności zjawisk. Wprowadzenie do tego obrazu kolejnej war- stwy, dotyczącej modeli gospodarczych, może istotnie wzbogacić dalsze wnioski badawcze. W swojej istocie jest to propozycja powrotu do idei K. Potkańskiego (Puszcza Radomska) oraz postulatów historii totalnej opartej o paradygmat przestrzeni geograficznej (F. Braudel).

Podstawą i punktem wyjścia dla analiz geograficzno-historycznych była i pozostaje obserwacja zjawisk z bliższej i dalszej przeszłości w ich kontekście przestrzennym. Opisana wyżej architektura warstwowa nie dotyczy jedynie poszczególnych elementów krajobrazu naturalnego, kulturowego czy społeczno-politycznego, ale wiąże je dodatkowo z odpowiednim przedziałem czasowym. Analizy krzyżowe, prowadzone między poszczególnymi warstwami tematycznymi, otrzymują $\mathrm{w}$ ten sposób dodatkowy element, dotyczący przemian w czasie zarówno samych zjawisk, jak też zależności między nimi. Proces wyjaśniania tych zjawisk, stanowiący istotny element pracy geografa historycznego, prowadzony głównie przy wykorzystaniu metod historycznych i geograficznych, powinien brać pod uwagę osiagnięcia także innych dziedzin, np. badania filologiczne (onomastyka).

Pewnym problemem pozostanie relacja między historią geografii (jako dyscypliny wiedzy), historią horyzontu geograficznego oraz historią kartografii a geografią historyczną. Przedmiotem badań tych dyscyplin nie jest bowiem przestrzeń geograficzna, ale jej wyobrażenia, percepcja i przedstawienia. Studia o takim charakterze są kluczowe i dają podstawy warsztatowe i źródłoznawcze dla geografii historycznej (dyscypliny pomocnicze). Kartografia historyczna oraz systemy informacji geograficznej będą w tej konfiguracji niezbędnymi narzędziami geografii historycznej (dyscypliny narzędziowe).

\footnotetext{
${ }^{111}$ D. R. Kelly, Oblicza historii. Badanie przeszłości od Herodota do Herdera, Warszawa 2010, s. 22.
} 


\section{Literatura}

Alexandrowicz S., Rozwój badań nad historia staropolskiej kartografii w latach 1918-1984, w: Dorobek polskiej historii kartografii, red. J. Janczak, W. Wernerowa, Warszawa 1993, s. 27-49.

Arnold S., Geografia historyczna, jej zadania $i$ metody, „Przegląd Historyczny” 28 (1929), nr 1, s. 91-120.

Arnold S., Geografia historyczna Polski, Warszawa 1951.

Atlas historyczny miast polskich, Legnica, t. 4, z. 6, red. R. Eysymontt, M. Goliński, Wrocław 2010.

Baker A.R.H., Geography and History: Bridging the Divide, Cambridge 2003.

Błaszczyk G., Geografia historyczna Wielkiego Księstwa Litewskiego. Stan i perspektywy badań, Poznań 2012.

Bohdanowicz J., Dzięcielski M., Zarys geografii historycznej i politycznej cywilizacji, Gdańsk 1996.

Borowicz D., Mapy narodowościowe Górnego Ślaska od potowy XIX wieku do II wojny światowej, Wrocław 2004.

Buczek K., Dzieje kartografii polskiej od XV do XVIII wieku. Zarys analityczno-syntetyczny, Wrocław-Warszawa-Kraków 1963.

Buczek K., Stan i potrzeby badań nad dziejami kartografii polskiej, w: Problemy nauk pomocniczych historii. Materiaty na III Konferencje poświęcona naukom pomocniczym historii, red. J. Szymański, Katowice 1974, s. 143-157.

Budzyński Z., Kresy potudniowo-wschodnie $w$ drugiej potowie XVIII wieku, t. 2, Atlas geograficzno-historyczny, Przemyśl-Rzeszów 2006.

Bujak F., Studja geograficzno-historyczne, Kraków 1925.

Bukowski W. i in., Edycja rękopiśmiennej mapy topograficznej Galicji z lat 1775-1783 (tzw. mapy Miega) z Archiwum Wojennego w Wiedniu, „Kwartalnik Historii Kultury Materialnej”, 59 (2011), nr 1, s. 101-106.

Chłapowski K., W sprawie pojęcia "geografia historyczna”, „Przegląd Geograficzny”, 68 (1996), z. 3-4, s. 479-483.

Courville S., Introduction à la géographie historique, Quebec 2004.

Czas i przestrzeń $w$ naukach geograficznych. Wybrane problemy geografii historycznej, red. M. Kulesza, Łódź 2008.
Czechowicz B., Historia kartografii Ślaska XIIXIX wieku, Wrocław 2004.

Darby H.C., The Relations of History and Geography: Studies in England, France and the United States, Exeter 2002.

Dobrowolska M., Metody kartograficzne w badaniach osadniczych, w: Pamiętnik IV. Powszechnego Zjazdu Historyków Polskich w Poznaniu 6-8 grudnia 1925, Lwów 1925, t. 1: Referaty, Sekcja VI.

Dobrowolska M., Przedmiot i metoda geografi historycznej. Uwagi o referacie prof. dra G. Labudy, „Przegląd Geograficzny”, 25 (1953), z. 1, s. 57-69.

Dobrowolska M., Przemiany środowiska geograficznego Polski do XV wieku, Warszawa 1961.

Dunin-Wasowicz T., Drogami średniowiecznej Polski. Studia z dziejów osadnictwa i kultury, Warszawa 2011.

Dunin-Wąowicz T., Klimat jako czynnik ksztattujacy środowisko cztowieka $w$ średniowieczu, w: Problemy nauk pomocniczych historii, t. 3, Katowice 1974, s. 17-35.

Dylik J., Województwo ze stolica bez antenatów. Geografia historyczna województwa tódzkiego, Łódź 1971.

Eberhardt P., Polska i jej granice. $Z$ historii polskiej geografii politycznej, Lublin 2004.

Ethington P.J., Placing the Past: "Groundwork" for Spatial Theory of History, "Rethinking History”, 11 (2007), nr 4, s. 465-493.

Geografia historyczna jako determinanta rozwoju nauk humanistycznych, red. M. Kulesza, Legnica-Łódź 2009.

Geografia osadnictwa i ludności w niepodlegtej Polsce. Lata 1918-1993, red. S. Liszewski, t. 2: Kierunki badań naukowych, Łódź 1994.

Gieysztor A., Zarys nauk pomocniczych historii, Warszawa 1948.

Golinnski M., Wokót socjotopografii późnośredniowiecznej Świdnicy, t. 1-2, Wrocław 2000-2003.

Gordziejew J., Socjotopografia Grodna w XVIII $w$. Toruń 2002.

Herbst S., Atlas na rozdrożu, w: tenże, Potrzeba historii czyli o polskim stylu życia, t. 2, Warszawa 1978, s. 462-469.

Historia geografii polskiej, red. A. Jackowski, S. Liszewski, A. Richling, Warszawa 2008. 
Historyczno-topograficzny atlas miast ślaskich, t. 1-2, red. P. Haslinger i in., Marburg 2010-2011.

Imago Poloniae. Dawna Rzeczpospolita na mapach, dokumentach i starodrukach $w$ zbiorach Tomasza Niewodniczańskiego, red. T. Niewodniczański, t. 1-2, Warszawa 2002.

Janczak J., Geografia historyczna - samodzielna dyscyplina czy tylko nauka pomocnicza?, w: Ojczyzna blizsza i dalsza. Studia historyczne ofiarowane Feliksowi Kirykowi w sześćdziesiąta rocznicę urodzin, red. J. Chrobaczyński, A. Jureczko, M. Śliwa, Kraków 1993, s. 83-89.

Jędrzejczyk D., Humanistyczna interpretacja krajobrazu kulturowego, w: Kulturowy aspekt badań geograficznych, red. E. Orłowska, J. Klementowski, Wrocław 2003, s. 68-73.

Jędrzejczyk D., U źródet polskiej myśli geopolitycznej, w: Z problematyki geopolitycznej ziem polskich, red. P. Eberhardt, Warszawa 2008, s. $15-28$.

Jodłowski A., Obraz Żupy Wielickiej i miasta Wieliczki na mapach Wilhelma Hondiusa z 1645 roku, Warszawa 2005.

Katalog atlasów 1801-1919, red. M. Łodyński, Warszawa 1965.

Katalog atlasów $i$ dziet geograficznych 1482 1800 (uzupetnienie), red. M. Łodyński, Warszawa 1963.

Katalog atlasów i dziet geograficznych 14821800, red. M. Łodyński, Warszawa 1961.

Katalog atlasów i dziet geograficznych 15281945, red. M. Łodyński, T. Paćko, Warszawa 1968.

Kelly D. R., Oblicza historii. Badanie przesztości od Herodota do Herdera, Warszawa 2010.

Kiełczewska-Zaleska M., Nowe kierunki studiów geograficzno-historycznych nad osadnictwem wiejskim, „Przegląd Geograficzny”, 35 (1963), z. 1, s. 3-19.

Kiełczewska-Zaleska M., O powstaniu i przeobrażaniu kształtów wsi Pomorza Gdańskiego, Warszawa 1956.

Konias A., Kartografia topograficzna państwa i zaboru pruskiego od II potowy XVIII wieku do potowy XX wieku, Słupsk 2010.

Konias A., Kartografia topograficzna Ślaska Cieszyńskiego $i$ zaboru austriackiego od potowy XVIII wieku do poczatku XX wieku, Katowice 2000.

Konopska B., Polskie atlasy historyczne - koncepcje i realizacje, Warszawa 1994.
Kościót w Polsce, t. 1-2, red. J. Kłoczowski, Kraków 1969 (zawiera mapy).

Kozłowska-Szczęsna T., Instytut Geografii i Przestrzennego Zagospodarowania Polskiej Akademii Nauk. Czterdzieści lat dziatalności 19531993, Warszawa 1994.

Kozyrski R., Bibliografia map i planów opracowanych w Instytucie Geografii Historycznej Kościota $w$ Polsce KUL $i$ wydanych $w$ latach 1956-2000, Lublin 2001.

Kulesza M., Zagadnienia morfogenezy $i$ rozplanowania miast średniowiecznych $w$ Polsce, Łódź 2011.

Labuda G., Uwagi o przedmiocie i metodzie geografii historycznej, „Przegląd Geograficzny”, 25 (1953), z. 1, s. 5-56.

Litak S., Atlas Kościota tacińskiego w Rzeczypospolitej Obojga Narodów w XVIII wieku, Lublin 2006.

Łopatecki K., Walczak W., Mapy i plany Rzeczypospolitej XVII w. znajdujace sie $w$ archiwach w Sztokholmie, t. 1-2, Warszawa 2011.

Manikowska H., Jerozolima - Rzym - Compostela. Wielkie pielgrzymowanie u schytku średniowiecza, Wrocław 2008.

Mapa w pracy historyka, red. T. Bogacz, B. Konopska, Wrocław-Warszawa 1999.

Miasta doby feudalnej $w$ Europie środkowowschodniej: przemiany spoteczne a uktady przestrzenne, red. A. Gieysztor, T. Rosłanowski, Warszawa 1976.

Mikulski K., Socjotopografia Torunia i Elblaga w późnym średniowieczu, Toruń 2006.

Moczulski L., Geopolityka. Korzyści i niebezpieczeństwa, „Przegląd Geopolityczny”, 1 (2009), s. s. 9-26.

Myga-Piątek U., Krajobraz kulturowy $w$ badaniach geograficznych, w: Krajobraz kulturowy. Aspekty teoretyczne i metodologiczne, red. U. Myga-Piątek, Sosnowiec 2005, s. 40-53. Myga-Piątek U., Historia, metody i źródta badań krajobrazu kulturowego, „Problemy Ekologii Krajobrazu”, 17 (2005), s. 71-77.

Olszewicz B., Dorobek polskiej historii geografii $i$ kartografii w latach 1945-1969, Warszawa 1971.

Olszewicz B., Kartografia polska XIX wieku. Przeglad chronologiczno-bibliograficzny, t 1-2, oprac. W. Wernerowa, Warszawa 1998.

Olszewicz B., Kartografia polska XIX wieku. Przeglad chronologiczno-bibliograficzny, t. 3, oprac. W. Wernerowa, J. Ostrowski, Warszawa 1999. 
Olszewicz B., Kartografia polska XVIII wieku. Przeglad chronologiczno-bibliograficzny, oprac. W. Wernerowa, J. Ostrowski, Warszawa 2003.

Olszewicz B., Kartografia polska XV-XVII wieku. Przeglad chronologiczno-bibliograficzny, oprac. W. Wernerowa, J. Ostrowski, Warszawa 2004.

Pamiętnik II Zjazdu Stowiañskich Geografów i Etnografów odbytego w Polsce w roku 1927, red. L. Sawicki, t. 2, Kraków 1930.

Piasecka J., Geografia historyczna i historia geografi, w: Gtówne kierunki badań geograficznych ośrodka wroctawskiego, red. J. Łoboda, P. Migoń, Wrocław 2005, s. 155.

Piskozub A., Dziedzictwo polskiej przestrzeni. Geograficzno-historyczne podstawy struktur przestrzennych ziem polskich, Wrocław 1987.

Piskozub A., Geografia historyczna międzymorza battycko-czarnomorskiego, rec. Leszek Moczulski: Narodziny Międzymorza. Uksztattowanie ojczyzn, powstanie panstw oraz uktady geopolityczne wschodniej części Europy w późnej starożytności i we wczesnym średniowieczu, Wydawnictwo Bellona, Warszawa 2007, ss. 827, „Przegląd Geopolityczny” 3 (2011), s. 221-240.

Piskozub A., Między historiozofia a geozofia, Gdańsk 1994.

Piskozub A., Morze $w$ dziejach cywilizacji, Toruń 1998.

Piskozub A., Rzeki $w$ dziejach cywilizacji, Toruń 2001.

Piskozub A., Transport $w$ dziejach cywilizacji, Toruń 1998.

Polonia: Atlas map z XVI-XVIII wieku, oprac. S. Alexandrowicz, L. Szaniawska, Warszawa 2005.

Potkański K., Pisma pośmiertne, oprac. F. Bujak, Poznań 2004 (zwłaszcza część zatytułowana Studia osadnicze), s. 78-262.

Prace Komisji Atlasu Historycznego Polski, t. 1-5 (1922-1948).

Przybytek D., Kartografia historyczna Ślaska XVII-XX wieku, Wrocław 2002.

Richling A., Perspektywy rozwoju ekologii krajobrazu, „Problemy Ekologii Krajobrazu”, 23 (2009), s. 1-10.

Rokosz M., O dalszej potrzebie i aktualnych metodach badań nad krajobrazem pierwotnym, w: Tradycje i perspektywy nauk pomocniczych historii w Polsce, Kraków 1995, s. 229-238.
Rola $i$ miejsce geografii osadnictwa $i$ ludności $w$ systemie nauk geograficznych, red. S. Liszewski, W. Maik, Bydgoszcz 2005, s. 10-15.

Rutkowski H., Atlas historyczny Polski, w: Towarzystwo Naukowe Warszawskie. Sto lat dziatalności, red. E. Wolnicz-Pawłowska, W. Zych, Warszawa 2009, s. 115-121.

Rutkowski H., Geografia historyczna, w: Wielka Encyklopedia Powszechna PWN, t. 4, Warszawa 1964, s. 184-185.

Rutkowski T.P., Nauki historyczne w Polsce 1944-1970. Zagadnienia polityczne i organizacyjne, Warszawa 2007.

Samsonowicz H., Przemiany osi drożnych w Polsce późnego średniowiecza, „Przegląd Historyczny” 64 (1973), z. 4, s. 697-716.

Schenk W., Historische Geographie, Darmstadt 2011.

Schlögel K., W przestrzeni czas czytamy. O historii cywilizacji i geopolityce, Poznań 2009.

Semkowicz W., O potrzebie i metodzie badań nad krajobrazem pierwotnym, w: Pamietnik IV. Powszechnego Zjazdu Historyków Polskich w Poznaniu 6-8 grudnia 1925, Lwów 1925, t. 1: Referaty, Sekcja VI.

Semkowicz W., Rozwój nauk pomocniczych historii w Polsce, Kraków 1948.

Sikora F., O Karolu Buczku jako twórcy „Stownika historyczno-geograficznego ziem polskich $w$ średniowieczu" z garścia wspomnień o nim, w: Karol Buczek (1902-1983). Cztowiek i uczony, red. D. Karczewski, J. Maciejewski, Z. Zyglewski, Kraków-Bydgoszcz 2004, s. 33-52.

Sirko M., Zarys historii kartografii, Lublin 1999.

Skrycki R., Dzieje kartografii Nowej Marchii do końca XVIII wieku, Warszawa 2008.

Słoń M., Miasta podwójne i wielokrotne w średniowiecznej Europie, Warszawa 2011.

Stownik historyczno-geograficzny ziem polskich $w$ średniowieczu, edycja elektroniczna, red. T. Jurek, oprac. informatyczne S. Prinke (dostęp: http://www.slownik.ihpan.edu.pl/, 19 maja 2012).

Stownik historyczno-geograficzny województwa krakowskiego $w$ średniowieczu, cz. IV, z. 3: Mieszczyński Staw-Mogilany, red. W. Bukowski, Kraków 2011.

Stownik historyczno-geograficzny województwa poznańskiego $w$ średniowieczu, cz. IV, z. 4: Squartnycze - Szytowyeczsko, red. T. Jurek, Poznań 2008. 
Smolka S., O przygotowawczych pracach do geografii historycznej Polski, w: Pamiętnik Pierwszego Zjazdu Historycznego Polskiego imienia Jana Dtugosza, odbytego w Krakowie $w$ czterechsetna rocznice jego śmierci, wyd. M. Bobrzyński, M. Sokołowski, Kraków 1881, s. 133-139.

Sobczyński M., Miejsce i rola powiatu w tradycji podziatu terytorialnego Polski, Łódź 2006.

Szady B., Geografia struktur religijnych i wyznaniowych $w$ Koronie $w$ II potowie XVIII wieku, Lublin 2010.

Szafer W., Analiza pytkowa w zastosowaniu do badań historii kultury materialnej cztowieka, „Kultura i Społeczeństwo”, 2 (1958), z. 1, s. 50-64.

Szulc H., Atlas historyczny wsi w Polsce, Warszawa 2002.

Szulc H., O nowych drogach badań w geografii historycznej, „Czasopismo Geograficzne”, 35 (1964), z. 1, s. 21-28.

Szymański J., Nauki pomocnicze historii, Warszawa 2006, s. 236-251.

Tatarkiewicz W., Kamieniecki Witold, w: Polski Stownik Biograficzny, t. 11, red. E. Rostworowski, Wrocław 1964-1965, s. 520-521.

Topodemograficzny atlas gmin i obszarów dworskich Pomorza Zachodniego w 1871 roku, red. D. Chojecki, Szczecin 2012.

Tyszkiewicz J., Cztowiek w środowisku geograficznym Polski średniowiecznej, Warszawa 1981.

Tyszkiewicz J., Geografia historyczna Polski $w$ średniowieczu, Warszawa 2003.

Tyszkiewicz J., Nauki historyczne i przyrodnicze $w$ badaniach lasów na ziemiach polskich, w: Ziemia i ludzie dawnej Polski: studia z geografii historycznej, red. A. Galos, J. Janczak, Wrocław 1976, s. 7-36.
Tyszkiewicz J., Środowisko naturalne i antroporegiony dorzecza Narwi przed 1000 lat, Wroclaw 1975.

Tyszkiewicz J., Uwagi nad krajobrazem środkowego Mazowsza i Warszawy w wiekach średnich, „Rocznik Warszawski”, 14 (1976), s. $49-82$

Wernerowa W., Dorobek ogólnopolskich konferencji historyków kartografii 1975-1995, w: Dwudziestolecie Zespotu Historii Kartografi, red. J. Ostrowski, W. Wernerowa, Warszawa 1995, s. 29-30.

Wieloarkuszowe mapy topograficzne ziem polskich, 1576-1870, cz. 1, red. T. Paćko, W. Trzebiński, Wrocław 1983, cz. 2, oprac. F. Uhorczak i in., Wrocław 1982.

Wiesiołowski J., Socjotopografia późnośredniowiecznego Poznania, Warszawa-Poznań 1982.

Wimmer J., Historische Landschaftskunde, Innsbruck 1885.

Withers Ch.W.J., Place and the "Spatial Turn" in Geography and in History, "Journal of the History of Ideas", 70 (2009), nr 4, s. 637658.

Wnęk K., Wtasność nieruchomości w Krakowie w potowie XIX w., Kraków 2011.

Województwo krakowskie w drugiej potowie XVI wieku, red. H. Rutkowski, Warszawa 2008.

Wprowadzenie do kartografii $i$ topografii, red. J. Pasławski, Wrocław 2006.

Zagadnienia geografii historycznej osadnictwa $w$ Polsce, red. M. Koter, J. Tkocz, ToruńŁódź 1994.

Ziemie Ruskie Rzeczypospolitej: epoka z przetomu wieku XVI-go na XVII-sty, oprac. A. Jabłonowski, Warszawa-Wiedeń 1889-1904 (Atlas historyczny Rzeczypospolitej Polskiej. Dział 2). 


\section{Historical geography in Poland - development and perspectives}

\section{Summary}

The present article deals with the main currents that have been developing in the Polish historical geography since the end of the $19^{\text {th }}$ century till now. A discussion on methodological and terminological matters has been left aside. Only the Introduction contains a short reference to those issues. The development of geographical-historical research is presented from two perspectives: institutional and thematic ones. A separate sub-chapter was devoted to cartography, both in the context of historical-cartographical studies and historical cartography. The review of the main institutions and research subjects considers the two major currents which developed in the Polish historical geography, especially since the middle of the $20^{\text {th }}$ century, namely the geographical and the historical ones. Despite the common subject of research, they often remained side by side, which was due to different methods applied and the different source basis. The Conclusion, which closes the article, indicates the contemporary tendencies in historical geography related to new subjects such as studies on the cultural landscape or landscape ecology. In addition, a question was set about the influence of technological changes, especially the introduction of systems of spatial information and spatiotemporal databases, on the development of historical geography and on changes in this field of research.

Słowa kluczowe: geografia historyczna, system informacji przestrzennej, czasoprzestrzenne bazy danych.

Keyw ords: historical geography, systems of spatial information, spatiotemporal databases.

dr hab. Bogumił Szady - profesor w Instytucje Historii KUL, kierownik Katedry Historii XVI-XVIII wieku i Pracowni Geoinformacji Historycznej, członek Zespołu Atlasu Historycznego Polski w Instytucie Historii PAN, (e-mail: szady@kul.pl; www: hgis.kul.lublin.pl/lab). 